\title{
Hydrodynamics and bioprocess considerations in designing bioreactors for cardiac tissue engineering
}

\author{
Ailing Teo ${ }^{1,2}$, Athanasios Mantalaris² and Mayasari Lim ${ }^{1 *}$ \\ Correspondence: mayasarilim@ntu.edu.sg \\ 'School of Chemical \& Biomedical Engineering, Nanyang Technological University, Nanyang Drive, Singapore. \\ ${ }^{2}$ Department of Chemical Engineering, Imperial College London, South Kensington Campus, Exhibition Road, London, UK.
}

\begin{abstract}
One of the most attractive fields in regenerative medicine and tissue engineering is cardiac cell regeneration due to the limited capacity of the heart muscle to regenerate itself. Recent advances in the field of stem cell bioprocess technology and biomaterials have accelerated progress in creating three-dimensional (3D) cardiac engineered tissues in vitro. Control of bulk and microscopic transport efficiency, which is determined by the choice of the bioreactor design and substrate material, poses direct influence on cell viability, proliferation and differentiation in vitro. This paper provides a critical review on the hydrodynamic considerations with respect to design aspects of the bioreactor and selection of substrate material for 3D cardiac tissue engineering.
\end{abstract}

Keywords: shear stress, flow dynamics, porosity, topography, stiffness, proliferation, differentiation

\section{Introduction}

Cardiovascular disease (CVD) is a leading cause of mortality in most developed countries accounting for $30 \%$ of all deaths worldwide in 2008 [1]. Current trends in obesity and the lack of a healthy lifestyle will likely lead to an increase in total population suffering from heart diseases, causing associated healthcare costs to increase in the United States [2]. Coronary heart disease accounts for $42 \%$ of the total mortality rates due to CVD. The narrowing of blood vessels in coronary heart disease patients limits the supply of blood to the heart and leads to myocardial ischemia. During myocardial ischemia, lack of oxygen and nutrient supply to cardiac muscle cells results in cell death of functional cardiomyocytes. The infarcted area undergoes inflammation and forms collagenous scar tissue, which lacks cardiac muscle cell functionality, thus the infarcted area will not be able to perform functions such as muscle contraction and electrical conduction. This will lead to decreased working capacity of the ventricular heart and increases the risk of heart failure. Current clinical interventions are still unable to restore the full function in the infarcted area and for patients who suffer from severe heart damage, the current option is to receive heart transplantation but the availability of heart donors is very scarce.

Cardiac tissue engineering offers a promising cell-based therapy to repair damaged heart muscles and achieve cardiac regeneration. However, current challenges remain in the generation of clinically relevant cell numbers, cardiac functionality and tissue integration. In therapeutic applications, local administration of $10^{8}-10^{9}$ total cell numbers of functional cardiomyocytes is often necessary to replace damaged ventricular cardiomyocytes in a post-infarct patient [3]. Conventional in vitro two-dimensional (2D) methods using tissue culture polystyrene (TCP) can be impractical for large-scale production. Moreover, cells cultured on TCP suffer from altered morphologies when they adhere to the hard surfaces. This can lead to unnatural cell behaviors that can differ significantly from the in vivo environment, which involves three-dimensional (3D) cell-cell and cell-matrix interactions. To this end, various groups have looked at developing 3D culture systems in the effort to replicate the physical and structural components of the in vivo microenvironment. In cardiac tissue engineering, the goal is therefore to design 3D environments that would bear greater resemblance to cardiomyocytes in the myocardium than 2D cultures [4-5].

In order to readily scale-up and achieve clinically relevant cell numbers, the use of bioreactors is necessary. In the culture of adherent cell types such as cardiomyocytes, cultures in bioreactors often requires the use of $3 \mathrm{D}$ scaffolds to achieve cell numbers, cell densities and morphological mimicry to those in the in vivo state. Several bioreactor cultures have successfully produced large numbers of cardiomyocytes in the magnitude of $10^{8}$ cell numbers [6-7]. However, hydrodynamics and scaffold properties should be considered in the design of bioreactors. Many different approaches were taken to address these issues independently. In this review, we discuss in greater detail the hydrodynamic and bioprocess considerations involved in the 
design of a scalable bioreactor and substrate architecture relevant to cardiac tissue engineering.

\section{Sources for regenerative therapies of cardiomyocytes} One of the first considerations for cardiac tissue engineering is the choice of cell source. The major types include mature cells, neonatal cells, adult stem cells and embryonic/induced pluripotent stem cells. Mature cardiomyocytes are the ideal cell source for their functional utility but the sourcing of these cells can be rather challenging. Mature cardiomyocytes also have very limited proliferative capacity, and this limits the cell quantity we can obtain to replace the infarcted area efficiently [8]. In addition, mature cardiomyocytes do not have the ability to repair damaged cardiomyocytes in the infarcted area. Thus, cell types with greater proliferative capacity, such as stem cells and progenitor cells, present greater promise as good cell sources of cardiac cell regeneration. Adult skeletal myoblasts, which are precursors of myocytes, have better proliferative capacities than mature cardiomyocytes and still contain contractile apparatus and lineage specificity [9]. Myoblasts can be isolated from the patient's own tissue, enabling autologous transplantation. However, as they derive from the skeletal muscle lineage, these cells still show that they are unable to integrate with the myocardium and result in problems like arrhythmias and fibrosis [10-11].

Adult stem cells are another potential source for cardiomyocytes. Cardiac stem cells (CSCs) and cardiac progenitor cells (CPCs) have the advantage of being primed to be cardiac-specific and are suitable candidates for regenerating the myocardium. They can form aggregates called cardiospheres and give rise to cardiomyocytes, smooth muscle cells and endothelial cells [12]. These cell types have demonstrated good potential for myocardial regeneration in vivo with improved cardiac functionality observed upon transplantation of the cardiospheres [13]. Cardiospheres and their derived cells are an attractive source for cardiac regeneration due to their high cardiogenic lineage specificity controllable under both in vitro and in vivo conditions while maintaining high self-renewal ability as immature progenitors [14-16]. However, it is hypothesized that their cardiac regenerative ability is not due to direct cardiomyogenesis of the transplanted cardiospheres but instead due to an indirect mechanism inducing endogenous regeneration of the host's myocardium [17]. Another study suggested that cardiomyogenesis observed by the cardiospheres could be due to myocardial tissue fragments, which were not thoroughly removed during the isolation process [18]. Thus, more studies are still required to determine their candidacy at this time. Despite their suitability as good cell source, isolation and expansion of these cells are complex processes. Challenges faced in cell expansion pose limitations to sufficient production of cardiomyocytes. Cardiac-derived adherent proliferating (CAP) cells, obtained from endomyocardial biopsies are easier to isolate and expand due to their higher proliferating capacity
[19]. These cells are also primed for cardiac specificity but so far initial studies indicate that they exhibit a preference for angiogenesis over cardiomyogenesis.

Another common source of adult stem cells is the bone marrow and umbilical cord; they comprise of two main types: hematopoietic stem cells (HSCs) and mesenchymal stem cells (MSCs). A few studies have shown that HSCs from bone marrow and umbilical cord blood may have cardiac regenerative potential [20-22]. In an in vivo study performed in mice, Jackson et al., showed that the highly enriched side population (SP) cells engrafted and differentiated into cardiomyocytes and endothelial cells in vivo [20]. In an in vitro study, Xaymardan et al., identified the bone marrow derived c-kit ${ }^{+}$cells as the cell population with an ability to form beating clusters in the presence of vascular endothelial and fibroblast growth factors [21]. Yet, other studies have contradicted these observations and showed that HSCs do not readily transdifferentiate into cardiomyocytes [23-24] and that their beneficial effects in transplantation studies were mostly due to cell fusion [25-26], thus they may have limited cardiac regenerative capacity. Given the contradicting observations made, therapeutic applications of HSCs for cardiac regeneration remain uncertain. Even if these cells were able to transdifferentaite into cardiomyocytes, they are very limited in cell numbers and may not be sufficient to make significant improvements in cardiac functionality.

MSCs remain the predominant source of adult stem cells supporting hematopoiesis and the maintenance of mesenchymal tissues [27]. MSCs from both bone marrow (BM-MSCs) and umbilical cord have demonstrated an ability to differentiate into osteogenic, adiopogenic, chondrogenic and cardiomyogenic lineages [28-29]. Human BM-MSCs can be used as allogeneic or autologous cell therapy [30-32]. One distinct advantage of BM-MSCs is their ability to inhibit inflammation and evade immune detection, which can then prevent rejection and improve recovery [33-36]. Despite these benefits, generation of cardiomyocytes from both human and non-human MSCs have not produced significant yields [37-39]. Endogenous myocardial regeneration using MSCs have not clearly demonstrated an ability to generate contractile tissue in vivo but have demonstrated safety and clinical benefits of the cell therapy [40-42]. However, more studies in quantifying the potential clinical benefit and elucidating the mechanism of action are necessary. The extraction of MSCs from bone marrow is also highly invasive and painful. On the other hand, MSCs derived from umbilical cord are extracted from the placenta or cord lining. Preclinical studies in placental derived MSCs showed its potential therapeutic utility for dilated cardiomyopathy [43] and its ability to differentiate into various cell types including cardiomyocytes [44]. Umbilical cord derived MSCs demonstrate potential clinical utility but are equally challenged in cell numbers. Another group of adult stem cells, which could be extracted via relatively non-invasive methods from abundant tissue, is adipose-derived stem cells (ASCs). So far, in vitro and in vivo evidences indicate the 

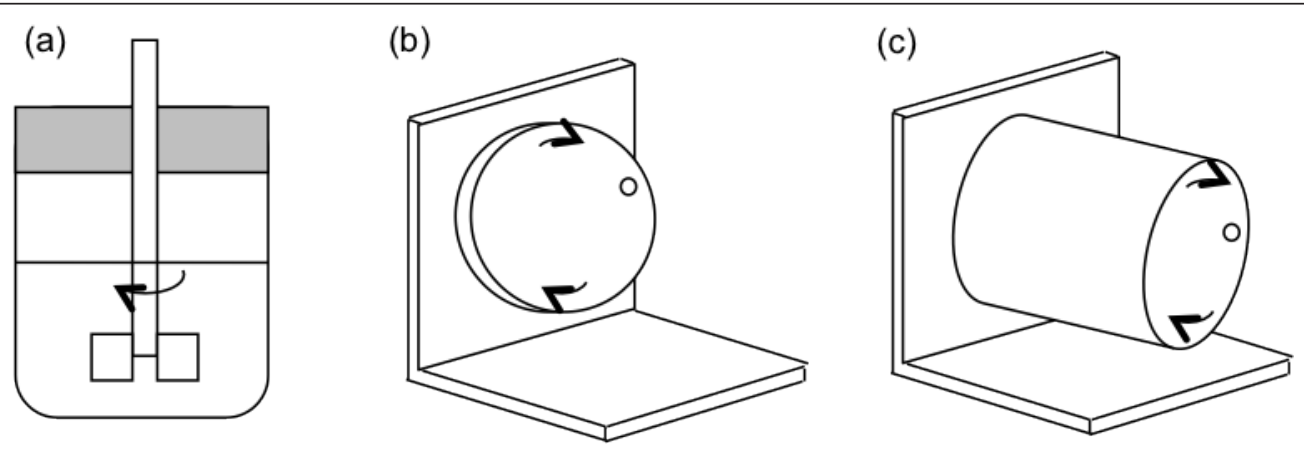

Figure 1. Common commercially available bioreactors for cardiomyogenesis. Brief schematic diagrams of (a) spinner flask with mixing impeller, (b) HARV system and (c) STLV system. Arrows are indicative of the vessel rotation.

ability of ASCs to differentiate into cardiomyocyte-like tissue [45-47]. ASCs demonstrate a potential utility for cardiomyocyte regeneration but more extensive studies are necessary to determine its candidacy at this time.

Embryonic stem cells (ESCs) represent a highly proliferative and pluripotent cell source that is able to generate high cell numbers. Among the various cell lineages, cardiomyocytes were reported as one of the first few cell populations identified that spontaneously differentiated in vitro [48]. In addition, ESCs are the only cell source that demonstrated equal tendencies in differentiation towards cardiogenesis and vasculogenesis. Such a characteristic can be highly beneficial to the regeneration of the myocardium with a vascular network [49-50]. However, spontaneous differentiation of ESCs could lead to teratoma formation, which would be detrimental to myocardium cell therapy. To resolve this issue, cardiogenic cells could be separated from other differentiated cells to enhance the purity of cardiomyocytes and vascular cells [51-52]. Nevertheless, in the roadmap of ESC usage for clinical application, problems like non-autologous transplantation, immune rejection, fibrosis, arrhythmia [53] and ethical concerns must be considered.

To resolve the ethical concerns in the use of embryos for obtaining ESCs, induced pluripotent stem cells (iPSCs) were proposed as an alternative. Cardiomyocyte differentiation from mouse iPSCs was first reported in 2008 [54-56] and further studies showed that human iPSC-derived cardiomyocytes were similar to those from ESCs in terms of their expression of cardiac markers and their activity in action potentials $[\mathbf{5 7}, \mathbf{5 8}]$. Induced pluripotent technology opens up possibilities for autologous transplantation from patient's own cells. However, transformation of harvested adult cells to iPSCs requires stable transfection, which is currently most reliably performed via viral methods. Unfortunately, such viral transfection could also lead to possible karyotypic abormailities. Thus, such a strategy could undermine its clinical suitability. Non-viral transfection methods like transposons [59], protein- and mRNA-based delivery, [60-62] and the use of small molecules [63] have been developed to replace retroviral vectors but are far less efficient. In addition, iPSCs alike ESCs have equal tendencies to form teratomas due to their likelihood for spontaneous differentiation.

In considering the range of possible cell sources, the quantity and quality of the final cell product must be considered. This means the capacity for cell expansion towards clinically relevant numbers, lineage specificity, and maturity of derived cardiomyocytes must be achievable from the selected cell source. Bioreactor design and cell culture parameters must be taken into consideration to ensure successful cardiac tissue engineering in vitro and its clinical relevance in vivo. Through a systematic approach in bioprocess engineering the design of future bioreactors and integration of wellsuited cell culture technology can ensure successful tissue engineering applications of specific cell types and lineages.

\section{Bioreactor design and bioprocess considerations}

Conventional methods for directing cardiomyogenesis in vitro are carried out in 2D flask/plate cultures, involving the use of TCP. Typically, cells are first expanded to reach the required cell numbers and then differentiated toward the cardiomyogenic lineage. The limited surface area on TCP restricts the cell densities achieved on 2D platforms, thus the expansion to clinically relevant cell numbers require the handling and usage of large number of TCP flasks. In the scale up of tissue engineering applications, bioreactors are frequently used with various possible configurations to meet specific applications and user preferences. Herein we provide a brief overview of different bioreactors that have been tested for both differentiation and maturation of cardiomyocytes.

One of the most commonly studied configurations is the spinner flask system $[\mathbf{6}, \mathbf{7}, \mathbf{5 2}, \mathbf{6 4}]$. To date, several companies are already providing commercially available configurations such as the Dasgip cellferm-pro system and Sartorius 2L Biostat MD. The basic spinner flask bioreactor design, as illustrated in Figure 1a, consists of an impeller, which provides a mixing action to ensure a well-mixed environment for cell culture. Mixing enhances homogeneity of the cell population 


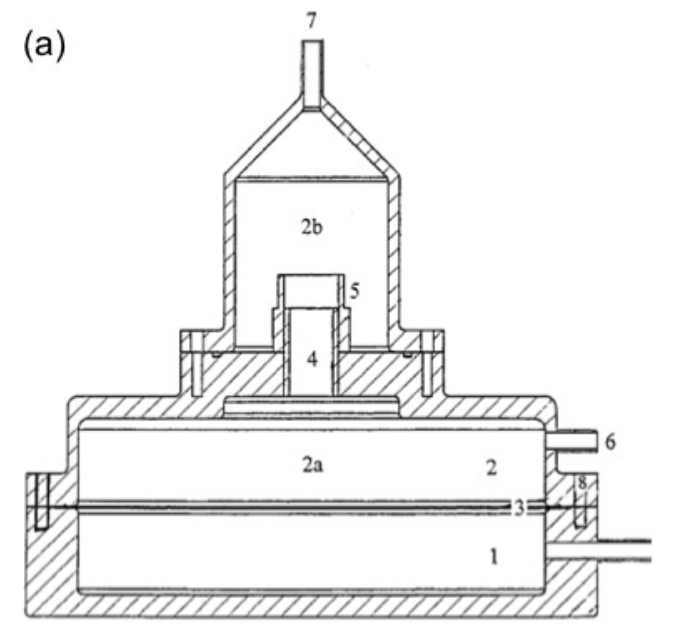

(b

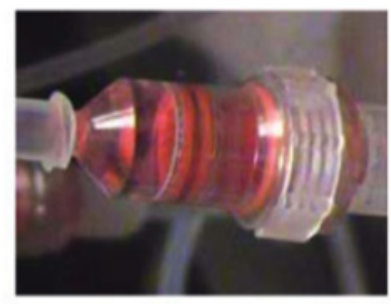

(1) (2)

(3)

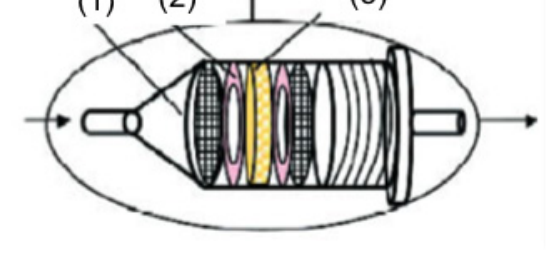

Figure 2. Examples of novel bioprocess platform incorporating pulsatile flow as mechanical stimuli for cardiomyogenesis. (a) Schematic diagram of a pulsatile bioreactor, incorporating perfusion for mechanical stimuli [54]. (b) Picture and schematic diagram of a perfusion chamber for cardiac tissue construct [57]. The construct (1) is placed in the chamber between two silicone gaskets (2) and two polypropylene meshes (3).

during proliferation, embryoid body (EB) formation (for ESC applications), and directed differentiation. Cells cultured in spinner flask bioreactors are either seeded on scaffolds or suspended as substrate-free aggregates $[7,52]$. The main advantages of this design are the ease in scaling up the bioreactor and the readily available monitoring capabilities. However, the impeller motion produces a shear stress environment that could lead to fatal cell damage and detrimental to cardiomyogenesis.

Another configuration that enables homogenous mixing without the use of impellers is the microgravity simulated rotating systems. A commercially available system is the rotary cell culture systems (RCCS) by Synthecon, which has also been studied for cardiomyogenesis $[65,66]$. This system was first designed by NASA to simulate cell culture under microgravity through rotation of the whole vessel. The rotating motion could provide homogeneous mixing under an ultra-low/no shear stress environment. The current commercial designs exist in two main configurations: the high-aspect rotating vessel (HARV, Figure 1b) and the slow-turning lateral vessel (STLV, Figure 1c). Both configurations are known to produce minimal shear stress and provide a suitable environment for cell cultures requiring low shear stress environment.

Besides the two commercial bioreactor designs highlighted, other novel bioreactors have been designed and studied by individual research groups. A notable feature in several labdesigned bioreactors is the use of pulsatile flow to introduce mechanical stimulation or shear stress to the cardiac constructs for directing cell differentiation or cell maturation [67-71]. For instance, Hoerstrup et al., designed a bioreactor [68], as illustrated in Figure 2a, where controlled, pulsed airflow introduced into the chamber (1) would cause an expansion of the silicone diaphragm (3). This expansion would then push the fluid though the channel (4) and cellular construct seeded in position (5), causing mechanical stimulation on the construct. Similarly, the pulsatile perfused bioreactor, designed by Brown et al., [71] (illustrated in Figure 2b), produced construct with increased hypertrophy and a higher percentage of elongated cardiomyocytes. Besides the use of mechanical stimuli, electrical stimulation could also be incorporated into the bioreactor platform and this has shown to enhance cardiomyogenesis from sources like ESCs [72-73]. Both the electrical stimulation studies on ESCs found that the impact on cardiac differentiation due to electrical stimulation involved the generation of reactive oxygen species.

The oxygen level inside the bioreactor is an important factor that could affect cardiomyocyte yield. Several studies showed that hypoxia (4\% oxygen level) affected cardiomyocyte differentiation of both human and murine ESCs; increased cardiomyocyte yield per murine ESC input [52] and increased expressions of cardiac markers in human ESCs [7] were observed, respectively. The benefits of hypoxia could be due to increased levels of hypoxia-induced factor (HIF-1a) which promotes cardiomyogenesis of ESCs [74]. However, hypoxia also aided in maintaining pluripotency and proliferation of ESCs, and resulted in decreased differentiation towards cardiomyocytes [75]. A more detailed review on the impact of oxygen on ESCs was discussed by Millman et al., [76]. Although it has been observed that in general, hypoxia was preferred for cardiac differentiation from ESCs, culturing 
Teo et al. Journal of Regenerative Medicine \& Tissue Engineering 2012,

neonatal cardiomyocytes in constructs at $20 \%$ oxygen level produced better contractile properties, cellular alignment and higher expression of sacromeric a-actinin [77-79]. Control of oxygen inside the bioreactor is essential in optimizing the yield and quality of cardiomyocyte generated from respective cell sources.

In designing a suitable bioreactor for cardiomyogenesis, a number of key design features must first be considered in the selection of a bioreactor configuration. These features include:

1. Culture conditions - Consider the feeding strategy, oxygen level, mechanical stimulation, etc.

2. Homogeneity of the culture environment - Consider the preferred mode of mixing operation to achieve the desired well-mixed environment.

3. Substrate for attachment - Consider whether the cells require a substrate for attachment to achieve 3D mimicry.

4. Scalability - Consider the factors necessary to design a scalable bioprocess.

These basic design questions serve to provide a guideline for one to consider the important features that should be integrated into the bioreactor design specified for cardiac tissue engineering applications. Distinct features of the bioreactor will impact characteristic parameters such as hydrodynamics. Thus, the selection of a bioreactor and execution of the bioprocess will result in different flow patterns affecting the shear environment and transport of soluble factors to the cell, which has a direct impact on cellular activities. For most tissue engineering applications including cardiomyogenesis, hydrodynamics in the bioreactor must be optimized to provide the suitable extracellular microenvironment for cell culture.

\section{Hydrodynamics effects on cardiomyogenesis}

Hydrodynamics is defined by fluid flows within the confined area of the cell culture platform. The static environment in conventional dish/flask cultures results in drastic concentration gradients and localized extremes that make large-scale bioprocesses difficult to monitor and control. Hydrodynamics in bioreactors can be optimized to alleviate such problems, making large-scale production easier. Different bioreactor configurations will result in different flow patterns that can affect cellular activities. In ex vivo generation of cardiomyocytes and 3D cardiac tissue constructs, hydrodynamics determines the macroscopic environmental conditions that will affect the shear stress and solute transport to the cells.

Simulation studies in hydrodynamics of different culture platforms can be modeled via computational fluid dynamics (CFD). The high efficiency in computational methods enables rapid interrogation of multiple parameters such as mass transfer efficacy, oxygen distribution and shear stress in various bioreactor platforms. Models from CFD simulations can generate relevant flow information to study the mass transfer efficiency of soluble factors to the cells. This not only identifies sensitive parameters that are significant to the hydrodynamics of the bioreactor, but can also serve to guide in designing a bioreactor for optimal cell growth. Such stimulation studies have already been accomplished in airlift bioreactors and perfused bioreactors for bone and cartilage tissue engineering [80-84].

Hydrodynamics effects have not only been shown in CFD simulation models but have also been observed experimentally. For instance, expansion of both human HSCs and ESCs were higher and sustained for a longer period under mixed environment in stirred systems and rotating wall vessels than in the static cultures $[\mathbf{6 6 , 8 5 - 8 7 ]}$. The improved cell expansion may be attributed to the improved transport of soluble factors. However, agitation speed in stirred systems must be optimized to produce a suitable shear stress environment for the different cell lines. This suitable environment should ensure maximum cellular viability, as observed for human HSCs [85], and optimal aggregation of EBs in the case of ESC cultures [66]. Evaluation of hydrodynamic effects on stem cell culture in general have been reviewed extensively by Kinney et al., [88] and Vunjak-Novakovic et al., [89]. Herein we will focus on the direct impact on cardiac tissue engineering applications and discuss potential implications in the bioreactor design.

\section{Shear stress}

Shear stress is introduced by the interaction of fluid molecules and cells due to fluid motion generated by mechanical movement of either the culture vessel or its components (such as rotary blades and flow perfusion). Differences in bioreactor configuration and their agitation will dictate the magnitude of shear stresses. Rotating wall vessels produce dynamic and laminar flow profiles that give rise to negligible shear stress [90-91]. Meanwhile, spinner flasks produce unidirectional and turbulent flow patterns that generate mild to considerable shear stresses. Rotational speed of the orbital-shaking or rotating wall vessel cultures will also affect the development of flow regions and magnitude of shear stresses. For instance, horizontal orbital-shaking vessels were found to produce uniform areas of low shear stresses of less than $2.5 \mathrm{dyn} / \mathrm{cm}^{2}$ at an orbital speed of 20-60 rpm [92]. Meanwhile, optimal speeds in rotating wall vessels are able to achieve a microgravity environment while preventing any deleterious interaction with the wall boundary. This was found to be between 20-25 rpm for encapsulated murine ESCs [93].

\section{Expansion and viability}

Shear stresses pose a direct impact on cell viability and proliferation. It is therefore critical that the shear environment is optimized to ensure high proliferation and viability of the cell sources. Bioreactor configurations that could provide a well-mixed environment have generally shown to improve proliferation of human-derived cell sources like ESCs, MSCs and HSCs [91,94-95]. In a study involving human ESCs, mild shear stress environment in a spinner flask system with glassball impellers (IGB) and shaker flask systems resulted in higher 
expansion fold and viability of ESCs than those observed in both the negligible shear environment in slow turning lateral vessels and the higher shear stress environment in spinner flask with paddle impellers. Other studies have also shown that shear stress higher than $2.5 \mathrm{dyn} / \mathrm{cm}^{2}$ would cause cellular damage and reduce cell expansion; this is true for both human ESC and neonatal rat cardiomyocyte cultures $[71,96,97]$. In the case of rat BM-MSC expansion, proliferation would only decrease at higher levels under laminar shear stress conditions $[98,99]$; when BM-MSCs were exposed to $5 \mathrm{dyn} / \mathrm{cm}^{2}$ of shear for 4 hours, proliferation decreased significantly [99]. However, shear conditions of $1 \mathrm{dyn} / \mathrm{cm}^{2}$ did not affect cell proliferation, indicating that BM-MSCs could still be cultured under a mild shear environment.

To translate the shear value to a more obvious attribute, we evaluate the impact with respect to flow rates. It has been observed that fluid jets at velocities higher than $1.6 \mathrm{~m} / \mathrm{s}$ would cause severe cell damage to attached cell layers of neonatal rat cardiomyocytes; causing them to detach from the substrate [100]. Conversely, a negligible shear environment in rotating wall vessels yield higher cell number and metabolic activity of these cardiomyocytes [90]. Rotary systems with insignificant shear environment produced laminar flow profiles, which serve to minimize cellular damage and increase aerobic metabolism, as compared to the unidirectional turbulent environment in spinner flasks. Laminar flow could also serve as a protective conditioning against apoptosis while turbulent flows would induce apoptosis [101].

\section{Embryoid body formation}

Embryoid body formation is considered a necessary step in the culture process of in vitro ESC differentiation. Similar to culture practices in traditional flask cultures, one main challenge in executing ESC differentiation in a bioreactor is the control of EB formation. However, unlike the static conditions maintained in most flask cultures, hydrodynamics and the impact of shear stresses in dynamic systems would play an important role in controlling EB formation. The next few studies have shown how shear stress would affect EB formation from humanderived ESC. Yirme et al., has demonstrated that the initiation of EB formation was highly sensitive to shear stresses, when human ESCs are directly seeded into the dynamic culture system under a shear environment, low EB concentration would result [91]. Thus a 2-day EB prearrangement period in static culture was recommended prior to seeding the cells into dynamic bioreactor systems. Subsequent to the prearrangement period, control of EB concentration, shape and size distribution was found to be more conducive under mild shear forces. Two stirred bioreactors (Erlenmeyer and IGB spinner flask) that were compared to Petri dish and STLV bioreactor cultures showed that mild shear stress in the dynamic culture systems produced smaller but more homogeneous EBs [91]. Another study also showed that the most uniform propagation of the human EB population can be achieved under conditions below $2.5 \mathrm{dyn} / \mathrm{cm}^{2}$ [96] forming a homogenous $E B$ population. Homogeneity of $E B$ populations appeared to follow an increasing trend with the speed of mixing as long as the shear stress was kept under this operational limit $[\mathbf{9 1 , 9 2 ] . ~}$

\section{Cardiomyogenesis}

The cardiac differentiation potential of human ESCs could be enhanced by mild shear stresses in the IGB spinner flask and the Erlenmeyer flask [91]. Increased number of contracting EBs (at least 30\%) were found in the spinner flask cultures and higher cardiac specific transcripts levels were observed in both spinner and Erlenmeyer flask cultures. Such observations were in agreement with those made by Sargent et al., in their human ESC studies, in which cardiac gene markers had the highest up-regulation in an environment with shear stress less than $2.5 \mathrm{dyn} / \mathrm{cm}^{2}$ [92]. For BM-MSCs, the highest levels of cardiac markers such as Nkx2.5, $\beta-\mathrm{MHC}$ and ANP were expressed when the rat BM-MSCs were first conditioned by a shear level of $10 \mathrm{dyn} / \mathrm{cm}^{2}$ for 24 hours in a parallel-plate flow chamber prior to differentiation. Under this shear condition, the microfilaments produced were the thickest and most well-oriented amongst all other experimental groups [102]. The impact of laminar shear stresses on BM-MSCs were also noted; any shear stress levels above $5 \mathrm{dyn} / \mathrm{cm}^{2}$ would inhibit rat BM-MSC proliferation [99]. The inhibition of cell proliferation in this study was associated to cell cycle arrest [99] while another study showed that flow induced shear stresses could simulate specific differentiation towards osteogenesis [103]. From the BM-MSCs studies, we can infer that shear stress could cause a phenotypic change in BM-MSCs. When the cells are subjected to a substantial level of shear stress, BM-MSCs could switch from proliferation to differentiation, leading to lineage specificity. Therefore, shear stress could have beneficial effects on cardiomyogenesis of BM-MSCs. When comparing the shear stress tolerance of ESCs and BM-MSCs, the tolerance of BM-MSCs appears to be higher than that of ESCs. This could be due to two reasons. First, the mentioned ESCs are derived from human while BM-MSCs are of rat origin. Second, the tolerance level of shear stress may also depend on exposure time. The higher optimal shear stress required for BM-MSCs could be due to the fact that BM-MSCs were subjected to a transient shear environment for only 24 hours while ESCs were subjected to a continuous shear environment for several days. In general, the overall benefits of mild shear environments on expansion and differentiation of both embryonic and adult stem cells suggest that mild shear stress would be preferred for cardiomyogenesis.

In the maturation of cardiomyocytes, intricate tissue structure and contractile properties become primary indicators in evaluating the success of an engineered cardiac tissue. Numerous studies were conducted to determine whether shear stress could affect and improve the ultrastructural and electrophysiological properties of cardiac constructs. For 
Teo et al. Journal of Regenerative Medicine \& Tissue Engineering 2012,

instance, a shear environment of $0.6 \mathrm{dyn} / \mathrm{cm}^{2}$ could increase the expression of cardiac markers like sarcomeric a-actin, cardiac troponin-T, Connexin-43 and adhesion molecule, $\mathrm{N}$-cad in encapsulated neonatal rat cardiomyocytes [97]. These constructs also produced cardiac muscle tissue with massive striations and well-developed sacromeres, and had regions where construct thickness exceeded $500 \mu \mathrm{m}$. This was in stark contrast to the aggregates of round cardiomyocytes in static and shear-free environment. Also, when cardiac constructs derived from neonatal rat cardiomyocytes were subjected to physiological shear levels of the vascular valves (1.54 dyn/ $\mathrm{cm}^{2}$ ) as imposed by a pulsatile flow, they exhibited better contractile properties like lower excitation threshold, higher maximum capture rate and higher contractile amplitude than those experiencing no shear or lower flow rates [71]. As shear stress was increased, electrophysiological properties such as the induction of extrasystoles also improved notably [100]. It has been suggested that the beneficial effects of shear stress is due to mechanical stimulation provided by the fluid movements and interactions, which induced subcellular changes, triggering action potential and mechanosensitive currents in maturing cardiomyocytes [100].

From these observations, controlled shear stress environments can serve as a mechanical stimulus to enhance maturation of cardiomyocytes. However, shear forces should not exceed certain shear stress limits. For example, studies have shown that shear environment above $1.6 \mathrm{dyn} / \mathrm{cm}^{2}$ would cause immature cardiomyocytes in the constructs to adopt a rounded morphology instead of forming striations $[104,105]$. One possible argument for their preference to low shear stress conditions could be derived from the in vivo situation. In vivo, cardiomyocytes are mainly found in the myocardium, which is between the inner lining endocardium and the epicardium. The endocardium consists primarily of endothelial cells. It serves as a buffer layer in the exchange of solutes to the myocardium and as a protective layer that shield the cardiomyocytes from blood flow during the pumping of ventricle chambers. Thus, when cardiomyocytes were subjected to high shear stress, they would show signs of dedifferentiation and adopt a rounded morphology.

Collectively controlled shear stress under mild conditions would enhance cardiomyogenesis for cardiac tissue engineering. To date, experimental studies suggested that the upper limits for induction of cardiomyogenesis from adult or embryonic stem cells would be $2.5 \mathrm{dyn} / \mathrm{cm}^{2}$ and maturation of neonatal cardiac cells would be $1.6 \mathrm{dyn} / \mathrm{cm}^{2}$. In designing a bioreactor, operational limits should not exceed the upper limits found in these experimental studies and for long-term cultures, the operational range should be even more conservative given the heightened sensitivity of the cells over a long period of exposure to shear stress.

\section{Mass transport}

Hydrodynamic flow affects the transport within a culture vessel and controls the availability of nutrients and soluble factors to the cells. For a static culture, transport of soluble components in the culture medium is mainly via diffusion. The lack of fluid flow in a static culture will result in concentration gradients within the bulk fluid, causing localized extreme conditions and posing several challenges in the control and monitoring of large-scale cell production. One of the main strategies to minimize non-homogeneous cell culture environments is to achieve uniform mixing in the culture vessel by introducing convective transport.

\section{Bulk convective transport}

In spinner flasks and rotating wall bioreactors, bulk fluid transport is facilitated via convection and provides a more homogenous environment throughout the vessel. Cultures would generally produce higher cellular expansion and better cell viability in such environments due to more efficient transport of soluble components, which supports cell activity $[89,93]$. Contractile properties of the cardiomyocytes along the peripheral surface of cardiac constructs were more homogeneous in a well-mixed environment [106]. Besides the higher cell number, better cell viability, and improved homogeneity, cultures in a well-mixed environment result in enhanced cardiomyogenesis. For instance, murine ESCs were found to express higher levels of cardiac markers like $\mathrm{Nkx2.5,a-MHC}$ and ANF in rotating wall vessels than in static cultures $[65,93]$.

Although mixing is beneficial for the cell culture, flow patterns inside the vessel are affected by the mode of mixing and this will impact the convective transport efficacy. Shaker flasks were found to have a lower mass transfer coefficient than spinner flasks and therefore would not be suitable for cell cultures requiring high oxygen demand such as during maturation of cardiomyocytes [107]. Agitation speed must also be adjusted to minimize concentration gradients and shear stresses that may be deleterious to the cells. In a comparative study between different culture systems, the rotating wall vessel had produced neonatal rat cardiomyocytes constructs of higher viability and higher expression levels of Connexin-43 and creatin kinase-MM than the spinner flasks [106]. Even though both bioreactors provided homogenous environments, the higher shear stress in spinner flask is detrimental to cardiomyogenesis. For rotating wall systems, the optimal rotation speed must achieve microgravity and maintain cellular constructs within the mid zone area to minimize collison to the wall boundary of the bioreactor. Experimental studies have confirmed that the rotation speed of the HARV rotating wall vessel system must operate above $25 \mathrm{rpm}$, when culturing hydrogel-encapsulated murine ESCs, in order to ensure uniform oxygen concentration above the 
(a)

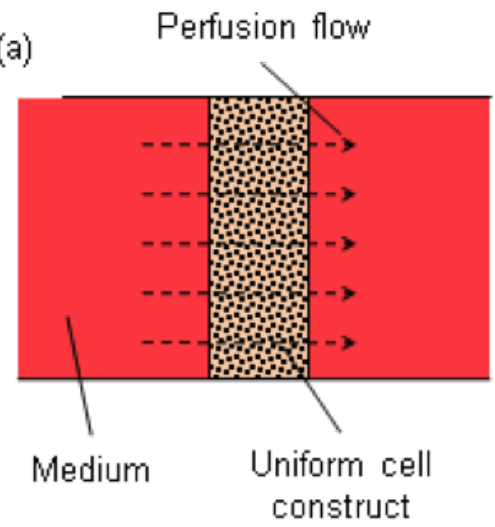

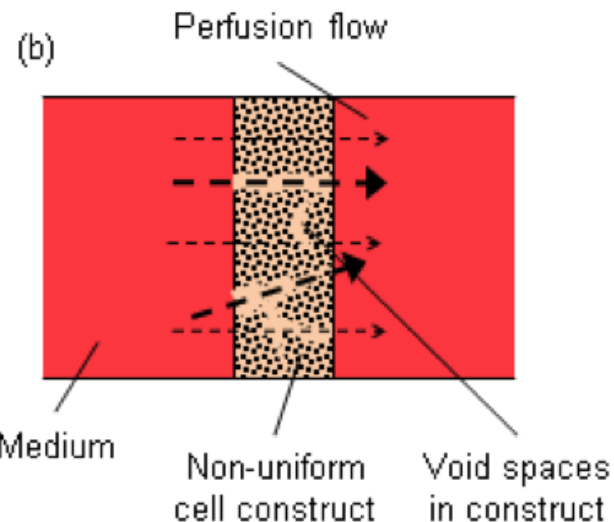

Figure 3. Diagrams of (a) total perfusion and (b) partial perfusion. (a) In total perfusion, medium flow through the uniform cell construct is uniformly distributed due to the uniform resistance. (b) In partial perfusion, medium flow is higher through the void spaces of the non-uniform cell construct, as indicated by the thicker arrows.

viable threshold [93]. Meanwhile cardiac constructs seeded in $600 \mu \mathrm{m}$ microbeads required a speed of $18 \mathrm{rpm}$ [108].

Solute transport within 3D cellular construct is governed by molecular diffusion. The transport efficacies within these constructs will therefore have a direct impact on the cell's microenvironment. Diffusion limitations can result in heterogeneous cell distribution and/or compromise cell viability in regions distant from the periphery of the construct. Cardiac constructs in both rotating wall vessels and spinner flasks were found to sustain a viable cellular region of up to $100 \mu \mathrm{m}$ in thickness along the peripheral region, while having an acellular core containing mostly apoptotic/dead cells. The latter is a consequence of diffusion constraints in oxygen $[90,109]$. A simple mass transfer simulation could be used to estimate the availability of nutrients inside $3 \mathrm{D}$ constructs and can be modeled based on diffusion and consumption rates of oxygen and relevant metabolites. With reference to a hepatocyte spheroids model [110-111], an increase in spheroid size would increase the core area, which would experience oxygen levels below the critical survival threshold. The critical radius of such spheroids could be calculated from the following:

$$
r=\sqrt{\frac{6 \mathrm{DH}\left(\mathrm{P}_{\mathrm{O} 2}-\mathrm{P}^{*}\right)}{\mathrm{O} 2 \text { consumption rate }}} \ldots \ldots \ldots .
$$

where D: Diffusion coefficient of oxygen within aggregate $\mathrm{H}$ : Henry constant of oxygen from air to medium $\mathrm{P}_{\mathrm{O} 2}$ : Partial pressure of oxygen in the air $P^{*}$ : Critical pressure of oxygen for cell survival

Although oxygen transport face diffusion constraints, the transport of glucose within a 3D construct is less affected by the spheroid size and its distance from the peripheral surface.
This is due to the fact that the effective diffusivity of glucose was not as significantly affected by the cell metabolic rate as that of oxygen. In general, effective transport throughout a 3D cellular construct requires the optimization of both convective and diffusive transport through careful selection of the bioreactor and design of the supporting scaffold.

\section{Perfusion}

Perfusion enables a continuous supply and control of culture parameters like $\mathrm{pH}$, oxygen, nutrients, and metabolites to maintain optimal operating conditions throughout the culture period. Two classifications have been defined: total perfusion and partial perfusion [112]. Total perfusion occurs when the flow is directed through a homogeneously and densely packed construct, which occupies the entire cross-sectional area of the perfused flow (illustrated in Figure 3a). Partial perfusion occurs in a non-homogeneously packed construct where channels are present or when constructs are freely suspended in culture (represented in Figure 3b). Both perfusion modes will result in different transport profiles in the construct and therefore will have different impact on cell numbers and cardiac differentiation.

Perfused cultures generally produced higher cell numbers than static cultures and were able to achieve expansion efficacy equivalent to the spinner flask cultures [104]. Furthermore, perfusion can be used to modulate oxygen availability to produce more uniform cell distribution throughout the cardiac construct and achieve more aerobic metabolism than both static and spinner flask cultures $[\mathbf{8 9}, \mathbf{1 0 4 , 1 1 3 ]}$. Perfusion rates tuned within operable conditions $0.2-3.0 \mathrm{~mL} / \mathrm{min}$ can control the availability of oxygen to cardiac cells inside the constructs [77]. However, transport within the construct between total perfusion and partial perfusion could differ drastically [112]. For total perfusion, cell density and viability are compromised 
Teo et al. Journal of Regenerative Medicine \& Tissue Engineering 2012,

in the regions that are further from the construct surfaces due to lower oxygen levels. Oxygen levels in the bulk medium could be increased to alleviate this problem, and thus provide an oxygen level above the critical survival threshold to the deeper regions. Under partial perfusion, regions with lower cell density will present lower resistance to the flow of medium. Thus medium would prefer to flow through such regions of lower resistance and result in significantly higher flow rates. When the percentage of low-resistant regions is insignificant, the construct would have a uniform resistance throughout the construct volume, and this would be equivalent to a cell distribution and transport profile to that in total perfusion. However, as the percentage of the low-resistant regions increases, cells will be more densely distributed along the low-resistant peripheral surfaces, which are exposed to the flow. Under such a scenario, diffusion within the construct would be more dominant than convection, resulting in similar phenomena as in the non-perfused cases.

Beneficial effects of perfusion on the extent of cardiac differentiation were also observed. Perfused cultures could produce cardiac constructs, from neonatal rat cardiomyocytes, which are more uniformly distributed throughout the construct [104] and have better contractile properties like twitch force and contraction frequencies than non-perfused cultures $[79,114]$. The role of perfusion in providing mechanical stimuli through shear stress was also demonstrated in a perfusion study through a series of constructs [77]. Their results showed that perfusion not only enhanced the induction of cardiomyogenesis, the shear stress from the perfused flow also enhanced the distribution and maturation of cardiomyocytes. In a recent study conducted by our group (unpublished data), the encapsulated murine ESCs in our novel perfused bioreactor produced earlier and higher cardiac expressions like cardiac Troponin-T and a-MHC upon differentiation, in comparison to the non-perfused cultures. Results from the reviewed studies showed that perfusion enhances homogeneity within the constructs and helps in maturation of cardiomyocytes. Meanwhile, the results from our group showed an earlier and higher induction of cardiomyogenesis in murine ESCs. These results were complementary, showing the overall benefit of incorporating perfusion into bioreactors for cardiac tissue engineering.

Contributions in hydrodynamics as shown by shear stresses and transport play a significant role in the success of cardiac tissue engineering in both macro and micro-scale. The availability of vital nutrients and oxygen is important in supporting overall cell viability and can impact the extent of differentiation. The design of dynamic bioreactors for 3D cardiac tissue engineering applications must therefore take the effects of hydrodynamics into careful consideration and the observations that have been made, highlighted the impact of hydrodynamics. These are summarized in Table 1.

\section{Scaffold architecture}

\section{Use of substrate}

To facilitate culture in scalable and dynamic bioreactors, cardiac cells and progenitor cells require a substrate for cell attachment. 3D constructs are preferred as higher cell densities per vessel volume can be achieved [115] and these constructs could provide a better mimicry to the in vivo state. For instance, ESC cultures in 3D can be achieved via the formation of embryoid bodies, cell seeding in a 3D scaffold or cell encapsulation in a hydrogel. The choice of substrate material and physical properties of the scaffold design would impact hydrodynamics in the micro-scale.

For cardiomyogenesis involving human and murine ESCs, many studies have directed cardiomyogenesis through the formation of embryoid bodies without attachment on any substrate material $[6,66,116-120]$. However, cellular products that are derived from the substrate-free method are highly dependent on operational parameters such as rotation and shear environment. This results in large variations in the cellular aggregate population, and imposes difficulty in controlling cell differentiation and maturation. Alternatively, many dynamic/suspension bioreactor cultures are conducted using microcarriers $[5,96]$ where the control of cell spheres and process scalability can be more readily achieved. The third possibility is to perform cell encapsulation of adult stem cells, ESCs, and cardiomyocytes [121-126]. Hydrogels, such as Ca-alginate, could be used to control the aggregate size during proliferation and showed to support long-term human ESC culture [126-128]. Moreover, encapsulated cells are less exposed to the shear environment. As reviewed in the previous section, studies on shear stresses have concluded that directing cells toward cardiomyogenesis in a low shear stress environment is generally more advantageous; cell encapsulation can also help in reducing shear stresses.

The selection of material as a suitable substrate for tissue engineering is the first important consideration. In general, the material should be biocompatible and sterilisable. In some instances, the mechanical properties of the materials must also match with those of the host tissue, and biodegradability if required should not exude cytotoxic components. There are two main categories of polymers that can be used for synthesis: naturally derived polymers and synthetic polymers. Substrates made from naturally derived polymers include alginate and collagen [129-132] which is more favorable for cell attachment. However, their mechanical properties can be more difficult to control and the inter-batch variability is subjective to their derived sources. Synthetic polymers like poly(ethylene glycol), poly(lactic acid) (PLA) and phosphoester, enable better tunablility of mechanical properties by changing parameters of the synthesis process. However, synthetic substrates generally do not promote cell adhesion as efficiently as those from naturally derived polymers. In such cases, extracellular matrix (ECM) derived peptides and proteins like Arg-Gly-Asp (RGD), gelatin and laminin, can be incorporated on the synthetic polymer chains to enable better cell adhesion and enhanced 
Table 1. Summary of hydrodynamic effects on cellular activities (cell proliferation and distribution and cardiomyogenesis).

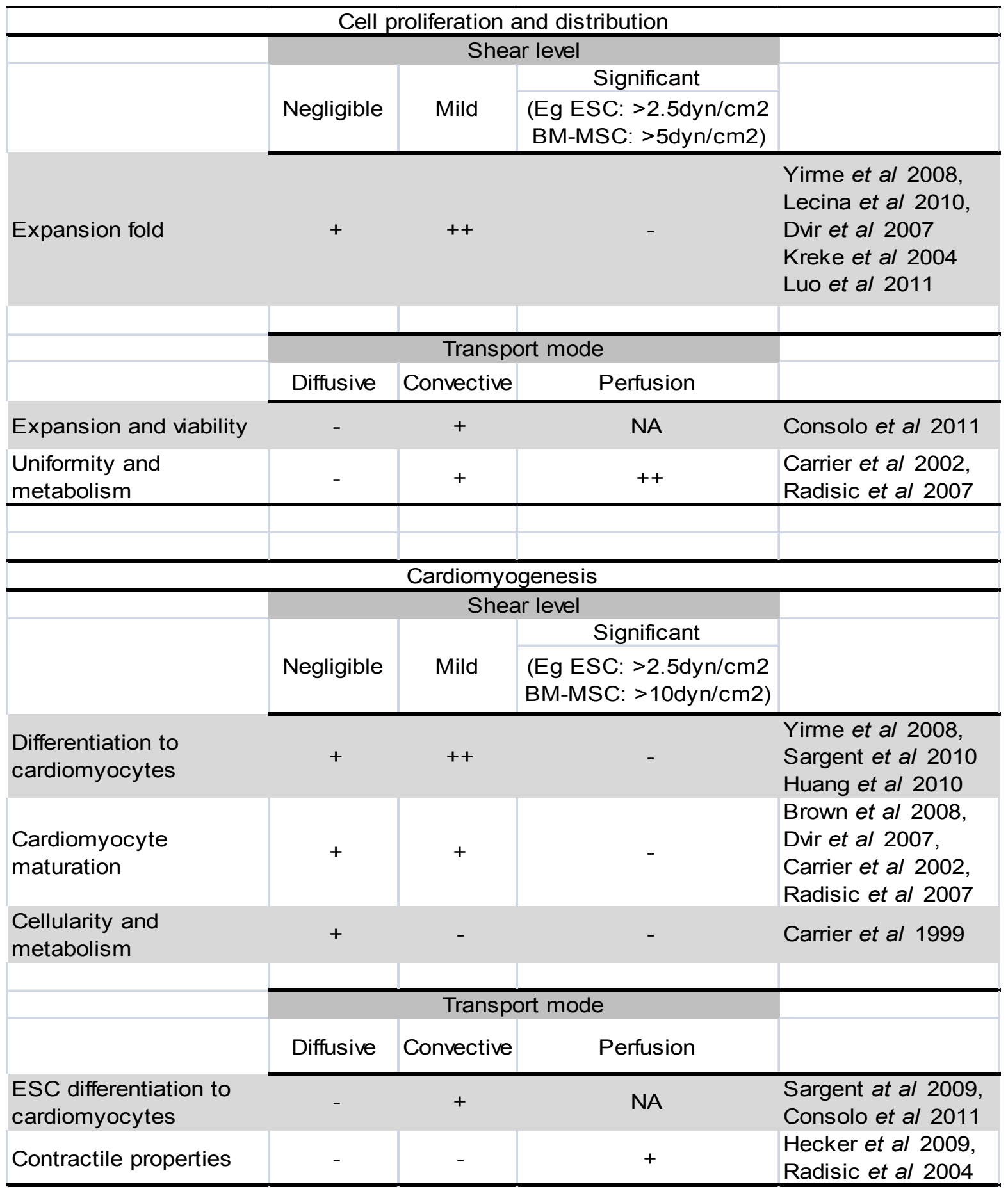

Negative sign ('-') indicates relatively negative impact; positive sign ('+') indicates moderate positive impact and double positive ('++') indicates significant positive impact 
cardiomyogenesis [133-136]. In utilizing synthetic polymers, both the physical anitropsy and mechanical properties of the polymer scaffold can be tuned to desired features to promote not only cell attachment but also cell alignment $[121,122]$. The use of RGD peptides has also proven to be very effective in improving cardiomyocyte viability and enhancing contractile performance of differentiated cells [124].

In selecting a suitable substrate, one of the major considerations is the substrate architecture, which plays a significant role in the transport efficacy of soluble factors. The overall architecture can be controlled by different fabrication techniques. For instance, a study was conducted to compare the impact of scaffold fabrication on the maturation of cardiomyocytes. Cells were seeded on scaffolds synthesized by two different techniques: thermally induced phase separation (TIPS) and electrospinning [137]. The TIPS method involves cooling of a polymer-solvent mixture into polymer-poor and polymer-rich phases, followed by extraction of the solvent (typically through sublimation) to give rise to a porous scaffold. In electrospinning, an applied high voltage will introduce charge-repulsion onto the polymer solution and spins the solution into a thin fluid jet onto a collector plate. As the solvent evaporates, it would leave behind a random network of nanofibres. Electrospun scaffolds have a larger surface area to volume ratio and are usually thinner than TIPS scaffolds. In this study, murine ESC-derived cardiomyocytes seeded on TIPS scaffolds were densely packed along the outer periphery about 100-200 $\mu \mathrm{m}$ in thickness while cells seeded on thinner electrospun nanofiber scaffolds had a more uniform cellular distribution [137]. Though expressions of cardiac markers (sacromeric-MHC and comnexin-43) were similar in both scaffolds, cardiomyocytes on TIPS scaffold had round morphology while electrospun scaffold gave rise to elongated cells. This indicated that the TIPS scaffold gave rise to a more embryonic phenotype while the architecture of electrospun scaffolds is preferential for cell maturation of ESC-dervied cardiomyocytes.

Scaffold fabrication techniques determine the overall architecture of the material and its properties such as topography, porosity and even stiffness. The availability of soluble factors surrounding the cell's microenvironment is largely controlled by porosity of the scaffold. This can impact cell function such as proliferation and differentiation, determining the fate in cardiomyogenesis. Other parameters such as surface topography and stiffness can also impact cell signalling mechanisms via cell-surface interactions. Table 2 summarizes the impact of these design parameters on cardiac tissue engineering and these examples are further

Table 2. Summary of effects of substrate architecture on cell proliferation and distribution and cardiomyogenesis

\begin{tabular}{|c|c|c|}
\hline \multicolumn{3}{|c|}{ Cell proliferation and distribution } \\
\hline Porosity & Enhanced oxygen transport for porous scaffolds with 100um channels and spacings & Radisic et al 2007 \\
\hline Topography & $\begin{array}{l}\text { Higher expansion fold and viability of neonatal cardiomyocytes on flat surface than on } \\
\text { mesh network due to higher specific cell concentration per area }\end{array}$ & Shah et al 2010 \\
\hline Stiffness & $\begin{array}{l}\text { Higher expansion fold and uniformity in substrate of less than } 100 \mathrm{kPa} \text { (low-medium } \\
\text { stiffness) }\end{array}$ & $\begin{array}{l}\text { Radisic et al 2004, Kenar et } \\
\text { al } 2011\end{array}$ \\
\hline \multicolumn{3}{|c|}{ Cardiomyogenesis } \\
\hline \multirow{3}{*}{ Porosity } & $\begin{array}{l}\text { Higher purity of cardiomyocytes from other stem-cell derived products in } 60 \mathrm{um} \text { - } \\
\text { channelled scaffolds with } 20 \text {-40um pore network }\end{array}$ & Madden et al 2010 \\
\hline & $\begin{array}{l}\text { Shift of immunoresponse to prohealing phenotype during transplantation in scaffolds } \\
\text { with } 30 \text {-40um pores }\end{array}$ & Madden et al 2010 \\
\hline & Better cardiomyocyte alignment during transplantation with increased porosity & Ifkovits et al 2010 \\
\hline \multirow{2}{*}{ Topography } & Increased alignment and contractile properties along grooved and channelled surfaces & $\begin{array}{l}\text { Aubin et al 2010, Fujita et al } \\
2006 \text {, Yin et al } 2004\end{array}$ \\
\hline & $\begin{array}{l}\text { Optimised width and spacing of patterns required to allow suitable time for cell } \\
\text { proliferation and alignment }\end{array}$ & Aubin et al 2010 \\
\hline Stiffness & Higher contraction amplitude and more beating areas on substrate of low stiffness & Shapira-Schweitzer et al 2007 \\
\hline
\end{tabular}




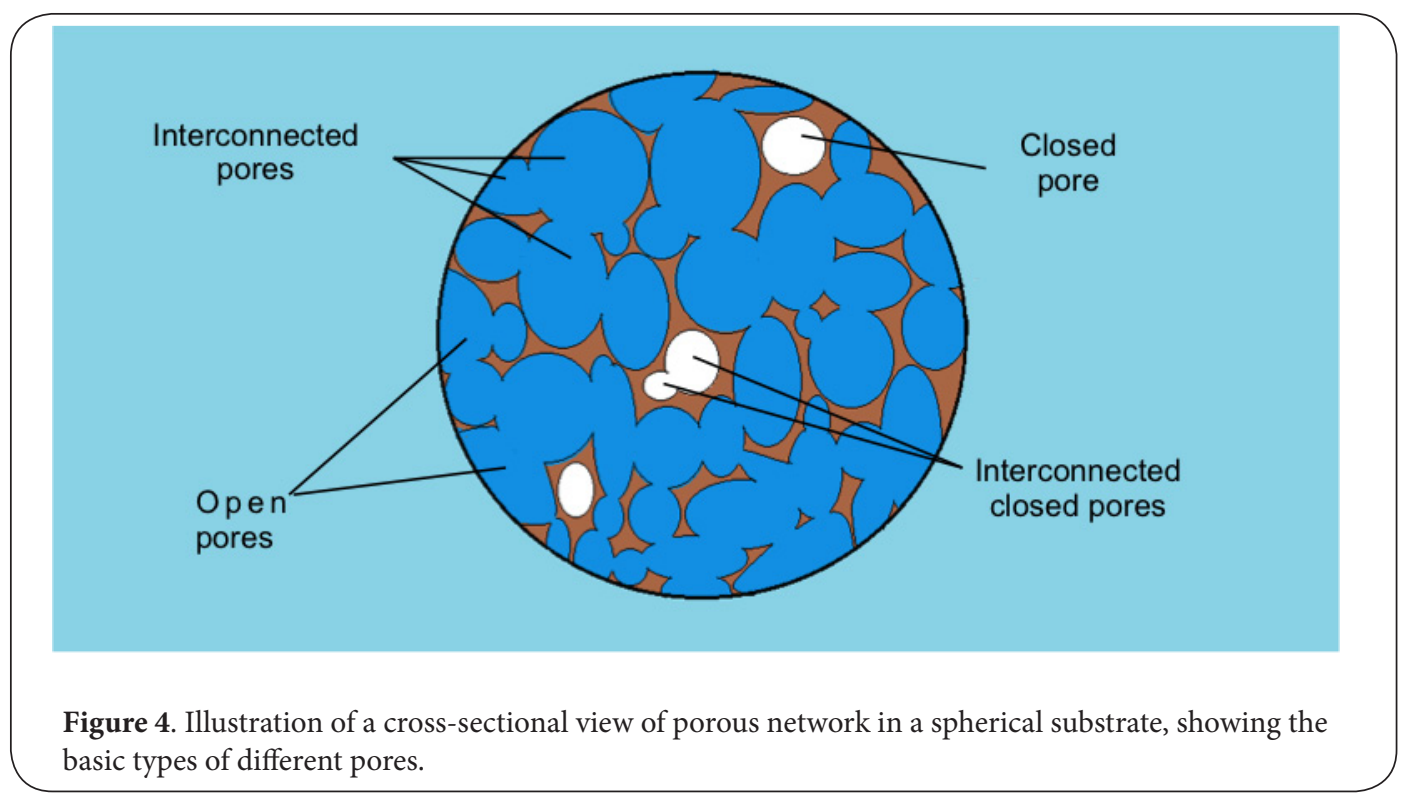

elaborated in the following sections.

\section{Porosity}

Porosity is a measure of void spaces in the scaffold and is a key design component in influencing the transport of soluble factors. In quantifying porosity of a scaffold, the percentage of void spaces and the level of interconnectivity, as illustrated in Figure 4, must both be considered. For tissue engineering applications, scaffolds with high interconnected porosity are preferred to minimize transport resistance and to promote cellular interaction and vascularization. In such highly interconnected and porous scaffolds, pore sizes and shapes could be varied to manipulate fluid transport and other cellular activities, as demonstrated by a number of studies.

Mesh scaffolds are usually random networks of pores synthesized by techniques like TIPS. Oxygen transport in random porous networks tends to have a higher degree of tortuisity than organized structures. Oxygen transport limitation in the mesh scaffolds therefore prohibits the formation of cardiac patches beyond $0.15 \mathrm{~cm}$, even with the aid of oxygen carriers. On the other hand, channelled scaffolds enabled oxygen supply throughout the whole construct with thickness up to $0.5 \mathrm{~cm}$ when oxygen carriers were used. A mathematical model was developed to show how oxygen distribution in the parallel channel array can be optimized by varying scaffold geometry [105].

Besides enhancing transport properties, pore size and channel spacing can be used to promote cardiomyocyte bundle orientation in vitro and enhance neovascularization in vivo. Madden et al., showed that a minimum spacing of $60 \mu \mathrm{m}$ channels was necessary for human ESC-derived cardiomyocyte cell seeding and the promotion of cardiomyocyte aggregate formation [138]. Interconnectivity of a porous network could also enhance purity of the human ESC-derived cardiomyocyte population by permitting non-cardiomyocyte cells to migrate through the network, which was optimized by channel walls with $20-40 \mu \mathrm{m}$ pores.

Furthermore, porosity could be used to control immunoresponse and cellular alignment in vivo. Scaffolds with $30-40 \mu \mathrm{m}$ pores produced maximum vascularization and minimal fibrous cap formation in an in vivo study [138]. In the same study, a shift of macrophage phenotype from proinflammatory $\mathrm{M} 1$ to prohealing $\mathrm{M} 2$ was also observed in 30-40 $\mu \mathrm{m}$ pores. Such a shift would reduce the chances of in vivo rejection of implanted scaffolds for cardiomyogenesis. Porosity could also increase the rate of cellular infiltration and ECM deposition thus producing better aligned cardiomyocytes post-transplantation [139]. This effect would likely be more pronounced when using a scaffold material that has a slower degradation rate.

\section{Topography}

Topography refers to the surface features of a material. In a substrate for cell culture, topography defines the surface patterns in which cells come in direct contact with. Numerous studies have reported the effects of topography on cardiomyocytes, enabling cell alignment and enhanced cardiomyocyte maturation. Grooved or channeled surfaces and an anisotropic geometry of scaffolds were shown to enhance the alignment and contractile properties of cardiomyocytes [140-143]. For instance, better cell alignment of neonatal rat cardiomyocytes were observed in accordion-like honeycomb scaffolds than in isotropc controls [141]. Abrasions on polyvinyl surfaces at $13 \mu \mathrm{m}$ wide and $700 \mathrm{~nm}$ deep were also found to 
Teo et al. Journal of Regenerative Medicine \& Tissue Engineering 2012,

be optimal for neonatal rat cardiomyoctye elongation [144]. Both studies support the fact that cell alignment, orientation and elongation, can be readily achieved by contact guidance and will be useful in cardiac tissue engineering.

Substrate topography can also influence cardiomyocyte properties. The effect of microtopography was studied using acellular porcine urinary bladder scaffold [145], which consisted of two distinct surfaces: a luminal side with smooth surface texture and an abluminal side with fine mesh network of nano- and microfibers. The results showed that the flat luminal surface had a higher density of neonatal cardiomyocytes with better contractile properties than the abuluminal surface. Contractile properties such as calcium recovery and hysteresis of cells grown on the luminal side also had superior performance. Hysteresis is a short-term cardiac memory of the previous contractile patterns, and is indicative of electric stability. Its presence in the cells is believed to help in preventing arrhythmias during transplantation.

Microarchitectures were successfully created in 3D hydrogels to control cell alignment recently [140]. The micropatterned hydrogels facilitated self-organization and elongation of fibroblast, myoblasts and cardiac progenitor cells to form aligned microconstructs. As the width of pattern channels decrease, the percentage of cells aligned along the direction of the axis would increase. When substrates with patterned surface were used, seeding density could also be optimized as higher seeding density would require shorter time for alignment of cells along the whole channel. These topographical effects were observed only for directionally orientated cells, but not for non-directionally orientated adherent cells like hepatoma cells [140]. Overall, 3D micropatterning techniques will become highly beneficial for the construction of cardiac tissue constructs.

\section{Stiffness}

Stiffness is the rigidity of a material and thus its ability to resist deformation when a force is applied. In tissue engineering, substrate stiffness could affect cellular proliferation and cellular activities like mineralization in osteogenesis and contraction in cardiomyogenesis. Substrate stiffness is usually controlled by concentrations of reagents such as the precursor or the monomer itself. Besides varying the material stiffness, concentration of the reagents could also affect the density of biologically active motifs in the substrate which will affect the cellular contractile properties [146].

On a substrate of low or medium stiffness $(<100 \mathrm{kPa})$, such as a $2 \%$ PGA scaffold, higher cardiomyocyte proliferation and a more uniform cell distribution were observed than that of a stiffer scaffold $[115,135]$. In addition, stiffer substrate was also found to be detrimental to cardiomyocyte maturation. In a study using PGS scaffolds and PEGlyated fibrinogen hydrogels to culture neonatal rat cardiomyocytes, lower contraction amplitude and less beating areas were observed in the stiffer materials [146]. Possible explanations on the detrimental effects of stiffer substrates could be that (1) stiffer substrates affected the contractile mechanism or (2) lower cell numbers and less uniform cell distribution in the stiffer scaffolds would yield lower cell-cell interaction, and this effectively inhibited cell maturation. Typically, substrates with a low stiffness would be more suitable for cardiac tissue engineering applications in promoting cell proliferation, uniformity of distribution and maturation. Moreover, substrates of lower stiffness would permit more flexibility in the construction of a myocardial patch; as in the case of a flexible microfibrous scaffold, which would be easier to be rolled into a tubular form than one with a higher stiffness [115].

\section{Conclusion and future directions}

In generating cardiomyocytes with clinically-relevant numbers, large-scale dynamic bioreactors will play an essential role in achieving the greatest potential. The control of hydrodynamic conditions in the macro- and microenvironment, tailored to cardiomyogenesis in vitro, is vital for optimizing the quality and reproducibility of engineered cell-tissue construct. Microarchitectural design of the substrate also plays a part in cell and tissue organization, which affects cell function. We summarized different parameters that could be used to provide optimal conditions for cell proliferation, embryoid body formation and cardiomyogenesis (Figure 5). The summary figure tells us that optimal shear conditions for cell proliferation and cardiomyogenesis should be generally mild and that perfusion is preferred in both proliferation and differentiation processes to facilitate expansion, homogeneity and maturation. In terms of substrate architecture, highly porous and interconnected scaffolds that are of low stiffness $(<100 \mathrm{kPa})$ are favored for both cell proliferation and differentiation. In addition, an organized topography would only play a role in cardiac differentiation.

The summary of these findings can serve as an excellent guideline in the selection and design of bioreactor cultures for cardiac cell tissue engineering. Depending on the cell source, this is the first step in optimizing the conditions to yield the required cellular products. However, control of culture conditions is imperative to large-scale manufacturing of engineered cells and tissues. The ability to incorporate in-situ monitoring and control measures is an essential component in large-scale production processes to ensure reproducibility. Technologies with such purposes have been established in the industries to guarantee product quality and uniformity and satisfy GMP requirements. At the current stage, largescale cultures for cardiac tissue engineering are still in the midst of establishing suitable bioreactor platforms and the monitoring and control technologies have not yet been fully-incorporated into these designs. With process analytical technology (PAT) initiative [147], real-time monitoring and control are now recommended and such technologies would become indispensible in the near future.

To date, many real-time monitoring methods are available for 


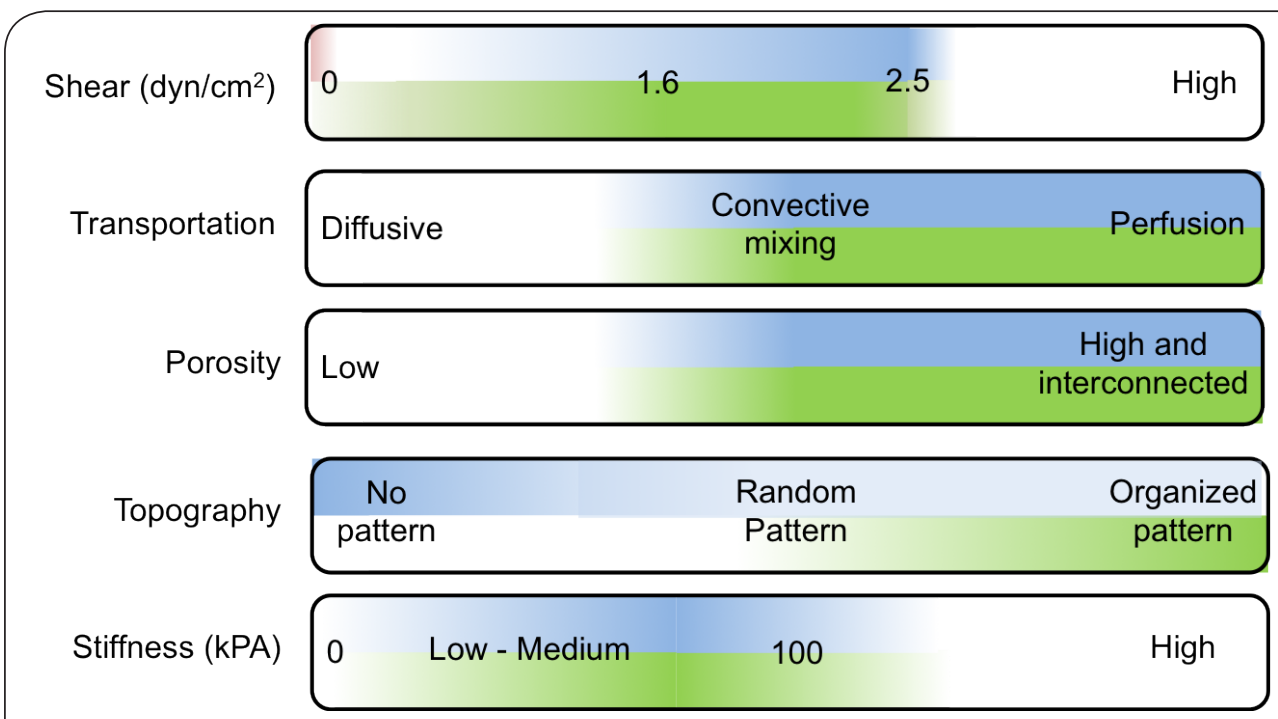

Figure 5. Overview of studied optimal conditions of shear environment, transportation, substrate topography and stiffness. A higher bar colour intensity indicates a more suitable condition. Blue bar represents cell proliferation; green bar represents cardiomyogenesis and red bar represents embryoid body formation.

bioreactors, including conventional electrochemical sensors, and non-invasive spectroscopic and optical technologies $[148,149]$. Integration of real-time monitoring technologies should minimize the amount of sample extracted for analysis and any disruption to the cell culture itself. Alternatively in-situ probes may be incorporated into the bioreactor and this is one of the most favored designs. However, in-situ methods face the challenges of maintaining component sterility and its incorporation into the sterile environment of the bioreactor. The design of a minimally invasive yet reliable monitoring technique remains as one of the main challenges to tissue engineering.

In reviewing the achievements and progress over the past decade, we have moved closer toward a better understanding of the needs and requirements in cardiac tissue engineering and have developed many tools and techniques that can enable us to achieve 3D functional cardiac cell tissue constructs. Despite improved understanding and new findings, functionally viable tissue-engineered cardiac constructs that can be used to repair/replace damaged heart tissues remain a significant challenge. Firstly, the choice of cell source for cardiac tissue engineering each faces different challenges that need to be addressed independently. For example, use of pluripotent stem cell resources will need to ensure homogeneity and purity of cardiomyocytes prior to transplantation. Next, transport limitations constrain the size of tissue engineered constructs and calls for the need of a vascularized network. Parameters required for tissue integration of cardiac cell patches that will enhance overall cardiac function is highly multifactorial and not easy to achieve.

\section{List of abbreviations}

ASC: Adipose-derived stem cell

BM-MSC: Bone marrow stem cell

CAP: Cardiac-derived adherent proliferating

CFD: Computational fluid dynamics

CSC: Cardiac stem cell

CPC: Cardiac progenitor cell

CVD: Cardiovascular diseases

EB: embryoid body

ECM: Extracellular matrix

ESC: Embryonic stem cell

HARV: High-aspect rotating vessel

HSC: Hematopoietic stem cell

IGB: Glass-ball impellers

iPSC: Induced pluripotent stem cell

MSC: Mesenchymal stem cell

PAT: Process analytical technology

RCCS: Rotary cell culture systems

STLV: Slow-turning lateral vessel

TCP: Tissue culture polystyrene

TIPS: Thermally induced phase separation

\section{Competing interests}

The authors declare that they have no competing interests.

\section{Authors' contributions}

All three authors were involved in the design and development of content for this manuscript. Miss Teo Ailing is the primary author while Dr. Mantalaris and Dr. Lim were involved in extensive editing of the manuscript.

\section{Publication history}

Editors: Rouel S. Roque, Touro University Nevada, USA. Leonard M. Eisenberg, New York Medical College, USA. EIC: Scott Argraves, Medical University of South Carolina, USA. Received: 11-Aug-2012 Revised: 06-Oct-2012

Accepted: 25-Oct-2012 Published: 14-Nov-2012 


\section{References}

1. Cardiovascular Diseases (CVDs). Link

2. Heart Disease to cost U.S $\$ 503$ billion in 2010 | Reuters. Link

3. McDevitt TC, Palecek SP: Innovation in the culture and derivation of pluripotent human stem cells. Curr Opin Biotechnol 2008, 19:527-533. | Article | PubMed

4. Zimmermann WH, Schneiderbanger K, Schubert P, Didie M, Munzel F, Heubach JF, Kostin S, Neuhuber WL, Eschenhagen T: Tissue engineering of a differentiated cardiac muscle construct. Circ Res 2002, 90:223-230. | Article | PubMed

5. Akins RE, Schroedl NA, Gonda SR, Hartzell CR: Neonatal rat heart cells cultured in simulated microgravity. In Vitro Cell Dev Biol Anim 1997, 33:337-343. | Article | PubMed

6. Schroeder M, Niebruegge S, Werner A, Willbold E, Burg M, Ruediger $M$, Field LJ, Lehmann J, Zweigerdt R: Differentiation and lineage selection of mouse embryonic stem cells in a stirred bench scale bioreactor with automated process control. Biotechnol Bioeng 2005, 92:920-933. | Article | PubMed

7. Niebruegge $S$, Bauwens $C L$, Peerani R, Thavandiran N, Masse $S$, Sevaptisidis E, Nanthakumar K, Woodhouse K, Husain M, Kumacheva $E$, Zandstra PW: Generation of human embryonic stem cell-derived mesoderm and cardiac cells using size-specified aggregates in an oxygen-controlled bioreactor. Biotechnol Bioeng 2009, 102:493-507. | Article | PubMed

8. Soonpaa MH, Kim KK, Pajak L, Franklin M, Field LJ: Cardiomyocyte DNA synthesis and binucleation during murine development. Am J Physiol 1996, 271:H2183-2189. | Article | PubMed

9. Menasche P: Skeletal myoblast for cell therapy. Coron Artery Dis 2005, 16:105-110. | Article | PubMed

10. Leobon B, Garcin I, Menasche P, Vilquin JT, Audinat E, Charpak S: Myoblasts transplanted into rat infarcted myocardium are functionally isolated from their host. Proc Natl Acad Sci U S A 2003, 100:78087811. | Article | PubMed Abstract | PubMed Full Text

11. Dib N, Michler RE, Pagani FD, Wright $S$, Kereiakes DJ, Lengerich R, Binkley P, Buchele D, Anand I, Swingen C, Di Carli MF, Thomas JD, Jaber WA, Opie SR, Campbell A, McCarthy P, Yeager M, Dilsizian V, Griffith BP, Korn R, Kreuger SK, Ghazoul M, MacLellan WR, Fonarow G, Eisen HJ, Dinsmore J, Diethrich E: Safety and feasibility of autologous myoblast transplantation in patients with ischemic cardiomyopathy: four-year follow-up. Circulation 2005, 112:1748-1755. | Article | PubMed

12. Matsuura K, Nagai T, Nishigaki N, Oyama T, Nishi J, Wada H, Sano M, Toko H, Akazawa H, Sato T, Nakaya H, Kasanuki H, Komuro I: Adult cardiac Sca-1-positive cells differentiate into beating cardiomyocytes. J Biol Chem 2004, 279:11384-11391. | Article | PubMed

13. Barile L, Messina E, Giacomello A, Marban E: Endogenous cardiac stem cells. Prog Cardiovasc Dis 2007, 50:31-48. | Article | PubMed

14. Ott HC, Matthiesen TS, Brechtken J, Grindle S, Goh SK, Nelson W, Taylor DA: The adult human heart as a source for stem cells: repair strategies with embryonic-like progenitor cells. Nat Clin Pract Cardiovasc Med 2007, 4 Suppl 1:S27-39. | Article | PubMed

15. Bartosh TJ, Wang Z, Rosales AA, Dimitrijevich SD, Roque RS: 3D-model of adult cardiac stem cells promotes cardiac differentiation and resistance to oxidative stress. J Cell Biochem 2008, 105:612-623. | Article I PubMed

16. Messina E, De Angelis L, Frati G, Morrone $S$, Chimenti S, Fiordaliso F, Salio M, Battaglia M, Latronico MV, Coletta M, Vivarelli E, Frati L, Cossu $\mathrm{G}$, Giacomello A: Isolation and expansion of adult cardiac stem cells from human and murine heart. Circ Res 2004, 95:911-921. | Article | PubMed

17. Marban E, Cingolani E: Heart to heart: Cardiospheres for myocardial regeneration. Heart Rhythm 2012, 9:1727-1731. | Article | PubMed

18. Andersen DC, Andersen P, Schneider M, Jensen HB, Sheikh SP: Murine "cardiospheres" are not a source of stem cells with cardiomyogenic potential. Stem Cells 2009, 27:1571-1581. | Article I PubMed

19. Haag M, Van Linthout S, Schroder SE, Freymann U, Ringe J, Tschope
C, Sittinger M: Endomyocardial biopsy derived adherent proliferating cells - a potential cell source for cardiac tissue engineering. I Cell Biochem 2010, 109:564-575. | Article | PubMed

20. Jackson KA, Majka SM, Wang H, Pocius J, Hartley CJ, Majesky MW, Entman ML, Michael LH, Hirschi KK, Goodell MA: Regeneration of ischemic cardiac muscle and vascular endothelium by adult stem cells. J Clin Invest 2001, 107:1395-1402. | Article | PubMed Abstract | PubMed Full Text

21. Xaymardan M, Cimini M, Fazel S, Weisel RD, Lu WY, Martin U, Harvey $\mathrm{RP}$, Li RK: c-Kit function is necessary for in vitro myogenic differentiation of bone marrow hematopoietic cells. Stem Cells 2009, 27:19111920. | Article | PubMed

22. Orlandi A, Pagani F, Avitabile D, Bonanno G, Scambia G, Vigna E, Grassi F, Eusebi F, Fucile S, Pesce M, Capogrossi MC: Functional properties of cells obtained from human cord blood CD34+ stem cells and mouse cardiac myocytes in coculture. Am J Physiol Heart Circ Physiol 2008, 294:H1541-1549. | Article | PubMed

23. Wagers AJ, Sherwood RI, Christensen JL, Weissman IL: Little evidence for developmental plasticity of adult hematopoietic stem cells. Science 2002, 297:2256-2259. | Article | PubMed

24. Murry CE, Soonpaa MH, Reinecke H, Nakajima H, Nakajima HO, Rubart M, Pasumarthi KB, Virag JI, Bartelmez SH, Poppa V, Bradford G, Dowell JD, Williams DA, Field LJ: Haematopoietic stem cells do not transdifferentiate into cardiac myocytes in myocardial infarcts. Nature 2004, 428:664-668. | Article | PubMed

25. Ishikawa F, Shimazu H, Shultz LD, Fukata M, Nakamura R, Lyons B, Shimoda K, Shimoda S, Kanemaru T, Nakamura K, Ito H, Kaji Y, Perry AC, Harada M: Purified human hematopoietic stem cells contribute to the generation of cardiomyocytes through cell fusion. FASEB J 2006, 20:950-952. | Article | PubMed

26. Alvarez-Dolado M, Pardal R, Garcia-Verdugo JM, Fike JR, Lee HO, Pfeffer K, Lois C, Morrison SJ, Alvarez-Buylla A: Fusion of bone-marrow-derived cells with Purkinje neurons, cardiomyocytes and hepatocytes. Nature 2003, 425:968-973. | Article | PubMed

27. Friedenstein AJ, Petrakova KV, Kurolesova Al, Frolova GP: Heterotopic of bone marrow. Analysis of precursor cells for osteogenic and hematopoietic tissues. Transplantation 1968, 6:230-247. | Article | PubMed

28. Makino S, Fukuda K, Miyoshi S, Konishi F, Kodama H, Pan J, Sano M, Takahashi T, Hori S, Abe H, Hata J, Umezawa A, Ogawa S: Cardiomyocytes can be generated from marrow stromal cells in vitro. J Clin Invest 1999, 103:697-705. | Article | PubMed Abstract | PubMed Full Text

29. Mangi AA, Noiseux N, Kong D, He H, Rezvani M, Ingwall JS, Dzau VJ: Mesenchymal stem cells modified with Akt prevent remodeling and restore performance of infarcted hearts. Nat Med 2003, 9:1195-1201. | Article | PubMed

30. Chin SP, Poey AC, Wong CY, Chang SK, Teh W, Mohr TJ, Cheong SK: Cryopreserved mesenchymal stromal cell treatment is safe and feasible for severe dilated ischemic cardiomyopathy. Cytotherapy 2010, 12:31-37. | Article | PubMed

31. Chen S, Liu Z, Tian N, Zhang J, Yei F, Duan B, Zhu Z, Lin S, Kwan TW: Intracoronary transplantation of autologous bone marrow mesenchymal stem cells for ischemic cardiomyopathy due to isolated chronic occluded left anterior descending artery. J Invasive Cardiol 2006, 18:552-556. | Article | PubMed

32. Hare JM, Traverse JH, Henry TD, Dib N, Strumpf RK, Schulman SP, Gerstenblith G, DeMaria AN, Denktas AE, Gammon RS, Hermiller JB, Jr., Reisman MA, Schaer GL, Sherman W: A randomized, double-blind, placebo-controlled, dose-escalation study of intravenous adult human mesenchymal stem cells (prochymal) after acute myocardial infarction. J Am Coll Cardiol 2009, 54:2277-2286. | Article

33. Aggarwal S, Pittenger MF: Human mesenchymal stem cells modulate allogeneic immune cell responses. Blood 2005, 105:1815-1822. | Article I PubMed 
34. Di Nicola M, Carlo-Stella C, Magni M, Milanesi M, Longoni PD, Matteucci P, Grisanti S, Gianni AM: Human bone marrow stromal cells suppress T-lymphocyte proliferation induced by cellular or nonspecific mitogenic stimuli. Blood 2002, 99:3838-3843. | Article | PubMed

35. Tse WT, Pendleton JD, Beyer WM, Egalka MC, Guinan EC: Suppression of allogeneic T-cell proliferation by human marrow stromal cells: implications in transplantation. Transplantation 2003, 75:389-397. | Article | PubMed

36. Le Blanc K, Tammik L, Sundberg B, Haynesworth SE, Ringden O: Mesenchymal stem cells inhibit and stimulate mixed lymphocyte cultures and mitogenic responses independently of the major histocompatibility complex. Scand J Immunol 2003, 57:11-20. | Article | PubMed

37. Assmus B, Honold J, Schachinger V, Britten MB, Fischer-Rasokat U, Lehmann R, Teupe C, Pistorius K, Martin H, Abolmaali ND, Tonn T, Dimmeler S, Zeiher AM: Transcoronary transplantation of progenitor cells after myocardial infarction. N Engl J Med 2006, 355:1222-1232. | Article | PubMed

38. Janssens S, Dubois C, Bogaert J, Theunissen K, Deroose C, Desmet W, Kalantzi M, Herbots L, Sinnaeve P, Dens J, Maertens J, Rademakers F, Dymarkowski S, Gheysens O, Van Cleemput J, Bormans G, Nuyts J, Belmans A, Mortelmans L, Boogaerts M, Van de Werf F: Autologous bone marrow-derived stem-cell transfer in patients with ST-segment elevation myocardial infarction: double-blind, randomised controlled trial. Lancet 2006, 367:113-121. | Article | PubMed

39. Lunde $K$, Solheim $S$, Aakhus $S$, Arnesen $H$, Abdelnoor M, Egeland T, Endresen K, llebekk A, Mangschau A, Fjeld JG, Smith HJ, Taraldsrud E, Grogaard HK, Bjornerheim R, Brekke M, Muller C, Hopp E, Ragnarsson $A$, Brinchmann JE, Forfang K: Intracoronary injection of mononuclear bone marrow cells in acute myocardial infarction. N Engl J Med 2006, 355:1199-1209. | Article | PubMed

40. Abdel-Latif A, Bolli R, Tleyjeh IM, Montori VM, Perin EC, Hornung CA, Zuba-Surma EK, Al-Mallah M, Dawn B: Adult bone marrow-derived cells for cardiac repair: a systematic review and meta-analysis. Arch Intern Med 2007, 167:989-997. | Article | PubMed

41. Lipinski MJ, Biondi-Zoccai GG, Abbate A, Khianey R, Sheiban I, Bartunek J, Vanderheyden M, Kim HS, Kang HJ, Strauer BE, Vetrovec GW: Impact of intracoronary cell therapy on left ventricular function in the setting of acute myocardial infarction: a collaborative systematic review and meta-analysis of controlled clinical trials. J Am Coll Cardiol 2007, 50:1761-1767. | Article | PubMed

42. Martin-Rendon E, Brunskill SJ, Hyde CJ, Stanworth SJ, Mathur A, Watt SM: Autologous bone marrow stem cells to treat acute myocardial infarction: a systematic review. Eur Heart J 2008, 29:1807-1818. | Article | PubMed

43. Ichim TE, Solano F, Brenes R, Glenn E, Chang J, Chan K, Riordan NH: Placental mesenchymal and cord blood stem cell therapy for dilated cardiomyopathy. Reprod Biomed Online 2008, 16:898-905. | Article | PubMed

44. Strom SC and Miki T, Placental stem cells and uses thereof, in United States Patent Application Publication. 2005, WO/2005/042703.

45. Planat-Benard V, Menard C, Andre M, Puceat M, Perez A, Garcia-Verdugo JM, Penicaud L, Casteilla L: Spontaneous cardiomyocyte differentiation from adipose tissue stroma cells. Circ Res 2004, 94:223-229. I Article | PubMed

46. Gaustad KG, Boquest AC, Anderson BE, Gerdes AM, Collas P: Differentiation of human adipose tissue stem cells using extracts of rat cardiomyocytes. Biochem Biophys Res Commun 2004, 314:420-427. Article | PubMed

47. Palpant NJ, Metzger JM: Aesthetic cardiology: adipose-derived stem cells for myocardial repair. Curr Stem Cell Res Ther 2010, 5:145-152. | Article | PubMed Abstract | PubMed Full Text

48. Doetschman TC, Eistetter H, Katz M, Schmidt W, Kemler R: The in vitro development of blastocyst-derived embryonic stem cell lines: formation of visceral yolk sac, blood islands and myocardium. J Embryol Exp Morphol 1985, 87:27-45. | Article | PubMed
49. Yang L, Anderson DE, Baecher-Allan C, Hastings WD, Bettelli E, Oukka M, Kuchroo VK, Hafler DA: IL-21 and TGF-beta are required for differentiation of human T(H)17 cells. Nature 2008, 454:350-352. | Article | PubMed Abstract | PubMed Full Text

50. Caspi O, Lesman A, Basevitch Y, Gepstein A, Arbel G, Habib IH, Gepstein $L$, Levenberg S: Tissue engineering of vascularized cardiac muscle from human embryonic stem cells. Circ Res 2007, 100:263-272. | Article | PubMed

51. Yamashita JK, Takano M, Hiraoka-Kanie M, Shimazu C, Peishi Y, Yanagi K, Nakano A, Inoue E, Kita F, Nishikawa S: Prospective identification of cardiac progenitors by a novel single cell-based cardiomyocyte induction. FASEB J 2005, 19:1534-1536. | Article | PubMed

52. Bauwens C, Yin T, Dang S, Peerani R, Zandstra PW: Development of a perfusion fed bioreactor for embryonic stem cell-derived cardiomyocyte generation: oxygen-mediated enhancement of cardiomyocyte output. Biotechnol Bioeng 2005, 90:452-461. | Article | PubMed

53. Chang MG, Tung L, Sekar RB, Chang CY, Cysyk J, Dong P, Marban E, Abraham MR: Proarrhythmic potential of mesenchymal stem cell transplantation revealed in an in vitro coculture model. Circulation 2006, 113:1832-1841. | Article | PubMed

54. Schenke-Layland K, Rhodes KE, Angelis E, Butylkova Y, HeydarkhanHagvall S, Gekas C, Zhang R, Goldhaber JI, Mikkola HK, Plath K, MacLellan WR: Reprogrammed mouse fibroblasts differentiate into cells of the cardiovascular and hematopoietic lineages. Stem Cells 2008, 26:1537-1546. | Article | PubMed Abstract | PubMed Full Text

55. Narazaki G, Uosaki H, Teranishi M, Okita K, Kim B, Matsuoka S, Yamanaka S, Yamashita JK: Directed and systematic differentiation of cardiovascular cells from mouse induced pluripotent stem cells. Circulation 2008, 118:498-506. | Article | PubMed

56. Mauritz C, Schwanke K, Reppel M, Neef S, Katsirntaki K, Maier LS, Nguemo F, Menke S, Haustein M, Hescheler J, Hasenfuss G, Martin U: Generation of functional murine cardiac myocytes from induced pluripotent stem cells. Circulation 2008, 118:507-517. | Article | PubMed

57. Zhang J, Wilson GF, Soerens AG, Koonce CH, Yu J, Palecek SP, Thomson $\mathrm{JA}$, Kamp TJ: Functional cardiomyocytes derived from human induced pluripotent stem cells. Circ Res 2009, 104:e30-41. | Article | PubMed Abstract | PubMed Full Text

58. Moretti A, Bellin M, Welling A, Jung CB, Lam JT, Bott-Flugel L, Dorn $T$, Goedel A, Hohnke C, Hofmann F, Seyfarth M, Sinnecker D, Schomig A, Laugwitz KL: Patient-specific induced pluripotent stem-cell models for long-QT syndrome. N Engl J Med 2010, 363:1397-1409. | Article | PubMed

59. Kaji K, Norrby K, Paca A, Mileikovsky M, Mohseni P, Woltjen K: Virusfree induction of pluripotency and subsequent excision of reprogramming factors. Nature 2009, 458:771-775. | Article | PubMed Abstract I PubMed Full Text

60. Zhou H, Wu S, Joo JY, Zhu S, Han DW, Lin T, Trauger S, Bien G, Yao S, Zhu Y, Siuzdak G, Scholer HR, Duan L, Ding S: Generation of induced pluripotent stem cells using recombinant proteins. Cell Stem Cell 2009, 4:381-384. | Article | PubMed

61. Kim D, Kim CH, Moon JI, Chung YG, Chang MY, Han BS, Ko S, Yang E, Cha KY, Lanza R, Kim KS: Generation of human induced pluripotent stem cells by direct delivery of reprogramming proteins. Cell Stem Cell 2009, 4:472-476. | Article | PubMed Abstract | PubMed Full Text

62. Plews JR, Li J, Jones M, Moore HD, Mason C, Andrews PW, Na J: Activation of pluripotency genes in human fibroblast cells by a novel mRNA based approach. PLoS One 2010, 5:e14397. | Article | PubMed Abstract | PubMed Full Text

63. Huangfu D, Osafune K, Maehr R, Guo W, Eijkelenboom A, Chen S, Muhlestein W, Melton DA: Induction of pluripotent stem cells from primary human fibroblasts with only Oct4 and Sox2. Nat Biotechnol 2008, 26:1269-1275. | Article | PubMed

64. Dang SM, Gerecht-Nir S, Chen J, Itskovitz-Eldor J, Zandstra PW: Controlled, scalable embryonic stem cell differentiation culture. Stem Cells 2004, 22:275-282. | Article | PubMed 
65. Sargent CY, Berguig GY, McDevitt TC: Cardiomyogenic differentiation of embryoid bodies is promoted by rotary orbital suspension culture. Tissue Eng Part A 2009, 15:331-342. | Article | PubMed

66. Gerecht-Nir S, Cohen S, Itskovitz-Eldor J: Bioreactor cultivation enhances the efficiency of human embryoid body (hEB) formation and differentiation. Biotechnol Bioeng 2004, 86:493-502. | Article | PubMed

67. Ge D, Liu X, Li L, Wu J, Tu Q, Shi Y, Chen H: Chemical and physical stimuli induce cardiomyocyte differentiation from stem cells. Biochem Biophys Res Commun 2009, 381:317-321. | Article | PubMed

68. Hoerstrup SP, Sodian R, Sperling JS, Vacanti JP, Mayer JE, Jr.: New pulsatile bioreactor for in vitro formation of tissue engineered heart valves. Tissue Eng 2000, 6:75-79. | Article | PubMed

69. Sodian R, Lemke T, Loebe M, Hoerstrup SP, Potapov EV, Hausmann $H$, Meyer R, Hetzer R: New pulsatile bioreactor for fabrication of tissueengineered patches. J Biomed Mater Res 2001, 58:401-405. | Article I PubMed

70. Rabkin E, Schoen FJ: Cardiovascular tissue engineering. Cardiovasc Pathol 2002, 11:305-317. | Article | PubMed

71. Brown MA, lyer RK, Radisic M: Pulsatile perfusion bioreactor for cardiac tissue engineering. Biotechnol Prog 2008, 24:907-920. | Article PubMed

72. Sauer H, Rahimi G, Hescheler J, Wartenberg M: Effects of electrical fields on cardiomyocyte differentiation of embryonic stem cells. J Cell Biochem 1999, 75:710-723. | Article | PubMed

73. Serena E, Figallo E, Tandon N, Cannizzaro C, Gerecht S, Elvassore N, Vunjak-Novakovic G: Electrical stimulation of human embryonic stem cells: cardiac differentiation and the generation of reactive oxygen species. Exp Cell Res 2009, 315:3611-3619. | Article | PubMed Abstract | PubMed Full Text

74. Ng KM, Lee YK, Chan YC, Lai WH, Fung ML, Li RA, Siu CW, Tse HF: Exogenous expression of HIF-1 alpha promotes cardiac differentiation of embryonic stem cells. J Mol Cell Cardiol 2010, 48:1129-1137. | Article | PubMed

75. Ramirez MA, Pericuesta E, Yanez-Mo M, Palasz A, Gutierrez-Adan A: Effect of long-term culture of mouse embryonic stem cells under low oxygen concentration as well as on glycosaminoglycan hyaluronan on cell proliferation and differentiation. Cell Prolif 2011, 44:75-85. | Article | PubMed

76. Millman JR, Tan JH, Colton CK: The effects of low oxygen on selfrenewal and differentiation of embryonic stem cells. Curr Opin Organ Transplant 2009, 14:694-700. | Article | PubMed

77. Carrier RL, Rupnick M, Langer R, Schoen FJ, Freed LE, Vunjak-Novakovic $\mathrm{G}$ : Effects of oxygen on engineered cardiac muscle. Biotechnol Bioeng 2002, 78:617-625. | Article | PubMed

78. Gerecht-Nir S, Radisic M, Park H, Cannizzaro C, Boublik J, Langer R, Vunjak-Novakovic G: Biophysical regulation during cardiac development and application to tissue engineering. Int J Dev Biol 2006, 50:233-243. | Article | PubMed

79. Hecker L, Khait L, Radnoti D, Birla R: Novel bench-top perfusion system improves functional performance of bioengineered heart muscle. J Biosci Bioeng 2009, 107:183-190. | Article | PubMed

80. Truscello S, Schrooten J, Van Oosterwyck H: A computational tool for the upscaling of regular scaffolds during in vitro perfusion culture. Tissue Eng Part C Methods 2011, 17:619-630. | Article | PubMed

81. Bannari R, Bannari A, Selma B, Proulx P: Mass transfer and shear in an airlift bioreactor: Using a mathematical model to improve reactor design and performance. Chem Eng Sci 2011, 66:2057-2067. | Article

82. Cinbiz MN, Tigli RS, Beskardes IG, Gumusderelioglu M, Colak U: Computational fluid dynamics modeling of momentum transport in rotating wall perfused bioreactor for cartilage tissue engineering. $J$ Biotechnol 2010, 150:389-395. | Article | PubMed

83. Sacco $R$, Causin $P$, Zunino $P$, Raimondi MT: A multiphysics/multiscale 2D numerical simulation of scaffold-based cartilage regeneration under interstitial perfusion in a bioreactor. Biomech Model Mechanobiol
2011, 10:577-589. | Article | PubMed

84. Brown A, Burke G, Meenan BJ: Modeling of shear stress experienced by endothelial cells cultured on microstructured polymer substrates in a parallel plate flow chamber. Biotechnol Bioeng 2011, 108:11481158. | Article | PubMed

85. Collins PC, Miller WM, Papoutsakis ET: Stirred culture of peripheral and cord blood hematopoietic cells offers advantages over traditional static systems for clinically relevant applications. Biotechnol Bioeng 1998, 59:534-543. | Article | PubMed

86. Liu Y, Liu T, Fan X, Ma X, Cui Z: Ex vivo expansion of hematopoietic stem cells derived from umbilical cord blood in rotating wall vessel. $J$ Biotechnol 2006, 124:592-601. | Article | PubMed

87. Cameron CM, Hu WS, Kaufman DS: Improved development of human embryonic stem cell-derived embryoid bodies by stirred vessel cultivation. Biotechnol Bioeng 2006, 94:938-948. | Article | PubMed

88. Kinney MA, Sargent CY, McDevitt TC: The multiparametric effects of hydrodynamic environments on stem cell culture. Tissue Eng Part $B$ Rev 2011, 17:249-262. | Article | PubMed Abstract | PubMed Full Text

89. Vunjak-Novakovic G, Radisic M, Obradovic B: Cardiac tissue engineering: effects of bioreactor flow environment on tissue constructs. Journal of Chemical Technology \& Biotechnology 2006, 81:485-490. | Article

90. Carrier RL, Papadaki M, Rupnick M, Schoen FJ, Bursac N, Langer R, Freed LE, Vunjak-Novakovic G: Cardiac tissue engineering: cell seeding, cultivation parameters, and tissue construct characterization. Biotechnol Bioeng 1999, 64:580-589. | Article | PubMed

91. Yirme G, Amit M, Laevsky I, Osenberg S, Itskovitz-Eldor J: Establishing a dynamic process for the formation, propagation, and differentiation of human embryoid bodies. Stem Cells Dev 2008, 17:1227-1241. | Article | PubMed

92. Sargent CY, Berguig GY, Kinney MA, Hiatt LA, Carpenedo RL, Berson RE, McDevitt TC: Hydrodynamic modulation of embryonic stem cell differentiation by rotary orbital suspension culture. Biotechnol Bioeng 2010, 105:611-626. | Article | PubMed

93. Consolo F, Bariani C, Mantalaris A, Montevecchi F, Redaelli A, Morbiducci U: Computational modeling for the optimization of a cardiogenic 3D bioprocess of encapsulated embryonic stem cells. Biomech Model Mechanobiol 2012, 11:261-277. | Article | PubMed

94. Timmins NE, Kiel M, Gunther M, Heazlewood C, Doran MR, Brooke G, Atkinson $\mathrm{K}$ : Closed system isolation and scalable expansion of human placental mesenchymal stem cells. Biotechnol Bioeng 2012, 109:18171826. | Article | PubMed

95. Chen X, Xu H, Wan C, McCaigue M, Li G: Bioreactor expansion of human adult bone marrow-derived mesenchymal stem cells. Stem Cells 2006, 24:2052-2059. | Article | PubMed

96. Lecina M, Ting S, Choo A, Reuveny S, Oh S: Scalable platform for human embryonic stem cell differentiation to cardiomyocytes in suspended microcarrier cultures. Tissue Eng Part C Methods 2010, 16:1609-1619. | Article | PubMed

97. Dvir T, Levy O, Shachar M, Granot $Y$, Cohen S: Activation of the ERK1/2 cascade via pulsatile interstitial fluid flow promotes cardiac tissue assembly. Tissue Eng 2007, 13:2185-2193. | Article | PubMed

98. Kreke MR, Goldstein AS: Hydrodynamic shear stimulates osteocalcin expression but not proliferation of bone marrow stromal cells. Tissue Eng 2004, 10:780-788. | Article | PubMed

99. Luo W, Xiong W, Zhou J, Fang Z, Chen W, Fan Y, Li F: Laminar shear stress delivers cell cycle arrest and anti-apoptosis to mesenchymal stem cells. Acta Biochim Biophys Sin (Shanghai) 2011, 43:210-216. | Article I PubMed

100. Kong CR, Bursac N, Tung L: Mechanoelectrical excitation by fluid jets in monolayers of cultured cardiac myocytes. J Appl Physiol 2005, 98:2328-2336; discussion 2320. | Article | PubMed

101. Poelmann RE, Gittenberger-de Groot AC: Apoptosis as an instrument in cardiovascular development. Birth Defects Res C Embryo Today 2005, 75:305-313. | Article | PubMed Abstract | PubMed Full Text 
102. Huang $Y$, Jia X, Bai K, Gong X, Fan Y: Effect of fluid shear stress on cardiomyogenic differentiation of rat bone marrow mesenchymal stem cells. Arch Med Res 2010, 41:497-505. | Article | PubMed

103. Yourek G, McCormick SM, Mao JJ, Reilly GC: Shear stress induces osteogenic differentiation of human mesenchymal stem cells. Regen Med 2010, 5:713-724. | Article | PubMed Abstract | PubMed Full Text

104. Carrier RL, Rupnick M, Langer R, Schoen FJ, Freed LE, Vunjak-Novakovic $\mathrm{G}$ : Perfusion improves tissue architecture of engineered cardiac muscle. Tissue Eng 2002, 8:175-188. | Article | PubMed

105. Radisic M, Deen W, Langer R, Vunjak-Novakovic G: Mathematical model of oxygen distribution in engineered cardiac tissue with parallel channel array perfused with culture medium containing oxygen carriers. Am J Physiol Heart Circ Physiol 2005, 288:H1278-1289. | Article | PubMed

106. Papadaki M, Bursac N, Langer R, Merok J, Vunjak-Novakovic G, Freed LE: Tissue engineering of functional cardiac muscle: molecular, structural, and electrophysiological studies. Am J Physiol Heart Circ Physiol 2001, 280:H168-178. | Article | PubMed

107. Zhang H, Williams-Dalson W, Keshavarz-Moore E, Shamlou PA: Computational-fluid-dynamics (CFD) analysis of mixing and gas-liquid mass transfer in shake flasks. Biotechnol Appl Biochem 2005, 41:1-8. | Article | PubMed

108. Kwon O, Devarakonda SB, Sankovic JM, Banerjee RK: Oxygen transport and consumption by suspended cells in microgravity: a multiphase analysis. Biotechnol Bioeng 2008, 99:99-107. | Article | PubMed

109. Bursac N, Papadaki M, Cohen RJ, Schoen FJ, Eisenberg SR, Carrier R, Vunjak-Novakovic G, Freed LE: Cardiac muscle tissue engineering: toward an in vitro model for electrophysiological studies. Am J Physiol 1999, 277:H433-444. | Article | PubMed

110. Sumaru K and Kanamori T: Optimal design of bio-hybrid systems with a hollow fiber scaffold: model analysis of oxygen diffusion/consumption. Biochem Eng J 2004, 20:127-136. | Article

111. Curcio E, Salerno S, Barbieri G, De Bartolo L, Drioli E, Bader A: Mass transfer and metabolic reactions in hepatocyte spheroids cultured in rotating wall gas-permeable membrane system. Biomaterials 2007, 28:5487-5497. | Article | PubMed

112. Coletti F, Macchietto S, Elvassore N: Mathematical modeling of three-dimensional cell cultures in perfusion bioreactors. Industrial \& engineering chemistry research 2006, 45:8158-8169. | Article

113. Radisic M, Park H, Gerecht S, Cannizzaro C, Langer R, Vunjak-Novakovic G: Biomimetic approach to cardiac tissue engineering. Philos Trans $R$ Soc Lond B Biol Sci 2007, 362:1357-1368. | Article | PubMed

114. Radisic M, Yang L, Boublik J, Cohen RJ, Langer R, Freed LE, VunjakNovakovic G: Medium perfusion enables engineering of compact and contractile cardiac tissue. Am J Physiol Heart Circ Physiol 2004, 286:H507-516. | Article | PubMed

115. Kenar H, Kose GT, Toner M, Kaplan DL, Hasirci V: A 3D aligned microfibrous myocardial tissue construct cultured under transient perfusion. Biomaterials 2011, 32:5320-5329. | Article | PubMed

116. Chen VC, Couture SM, Ye J, Lin Z, Hua G, Huang HI, Wu J, Hsu D, Carpenter MK, Couture LA: Scalable GMP compliant suspension culture system for human ES cells. Stem Cell Res 2012, 8:388-402. | Article | PubMed Abstract | PubMed Full Text

117. He W, Ye L, Li S, Liu H, Wang Q, Fu X, Han W, Chen Z: Stirred suspension culture improves embryoid body formation and cardiogenic differentiation of genetically modified embryonic stem cells. Biol Pharm Bull 2012, 35:308-316. | Article | PubMed

118. Shafa M, Krawetz R, Zhang Y, Rattner JB, Godollei A, Duff HJ, Rancourt $D E$ : Impact of stirred suspension bioreactor culture on the differentiation of murine embryonic stem cells into cardiomyocytes. BMC Cell Biol 2011, 12:53. | Article | PubMed Abstract | PubMed Full Text

119. Rungarunlert S, Klincumhom N, Bock I, Nemes C, Techakumphu M, Pirity MK, Dinnyes A: Enhanced cardiac differentiation of mouse embryonic stem cells by use of the slow-turning, lateral vessel (STLV) bioreactor. Biotechnol Lett 2011, 33:1565-1573. | Article | PubMed
120. Lu S, Liu S, He W, Duan C, Li Y, Liu Z, Zhang Y, Hao T, Wang Y, Li D, Wang C, Gao S: Bioreactor cultivation enhances NTEB formation and differentiation of NTES cells into cardiomyocytes. Cloning Stem Cells 2008, 10:363-370. | Article | PubMed

121. Li Z, Guo X, Palmer AF, Das H, Guan J: High-efficiency matrix modulusinduced cardiac differentiation of human mesenchymal stem cells inside a thermosensitive hydrogel. Acta Biomater 2012, 8:3586-3595. | Article | PubMed

122. Moshaverinia A, Chen C, Akiyama K, Ansari S, Xu X, Chee WW, Schricker $\mathrm{SR}$, Shi S: Alginate hydrogel as a promising scaffold for dental-derived stem cells: an in vitro study. J Mater Sci Mater Med 2012. | Article | PubMed

123. Liu J, Xu HH, Zhou H, Weir MD, Chen Q, Trotman CA: Human umbilical cord stem cell encapsulation in novel macroporous and injectable fibrin for muscle tissue engineering. Acta Biomater 2012. | Article | PubMed

124. Yuan Ye K, Sullivan KE, Black LD: Encapsulation of cardiomyocytes in a fibrin hydrogel for cardiac tissue engineering. J Vis Exp 2011. | Article | PubMed Abstract | PubMed Full Text

125. Gerecht-Nir S, Cohen S, Ziskind A, Itskovitz-Eldor J: Three-dimensional porous alginate scaffolds provide a conducive environment for generation of well-vascularized embryoid bodies from human embryonic stem cells. Biotechnol Bioeng 2004, 88:313-320. | Article | PubMed

126. Siti-Ismail N, Bishop AE, Polak JM, Mantalaris A: The benefit of human embryonic stem cell encapsulation for prolonged feeder-free maintenance. Biomaterials 2008, 29:3946-3952. | Article | PubMed

127. Gerecht-Nir S, Cohen S, Ziskind A, Itskovitz-Eldor J: Three-dimensional porous alginate scaffolds provide a conducive environment for generation of well-vascularized embryoid bodies from human embryonic stem cells. Biotechnol Bioeng 2004, 88:313-320. | Article | PubMed

128. Jing D, Parikh A, Tzanakakis ES: Cardiac cell generation from encapsulated embryonic stem cells in static and scalable culture systems. Cell Transplant 2010, 19:1397-1412. | Article | PubMed Abstract | PubMed Full Text

129. Engler AJ, Carag-Krieger C, Johnson CP, Raab M, Tang HY, Speicher DW, Sanger JW, Sanger JM, Discher DE: Embryonic cardiomyocytes beat best on a matrix with heart-like elasticity: scar-like rigidity inhibits beating. J Cell Sci 2008, 121:3794-3802. | Article | PubMed Abstract | PubMed Full Text

130. Li RK, Yau TM, Weisel RD, Mickle DA, Sakai T, Choi A, Jia ZQ: Construction of a bioengineered cardiac graft. J Thorac Cardiovasc Surg 2000, 119:368-375. | Article | PubMed

131. Dar A, Shachar M, Leor J, Cohen S: Optimization of cardiac cell seeding and distribution in 3D porous alginate scaffolds. Biotechnol Bioeng 2002, 80:305-312. | Article | PubMed

132. Bai XP, Zheng HX, Fang R, Wang TR, Hou XL, Li Y, Chen XB, Tian WM: Fabrication of engineered heart tissue grafts from alginate/collagen barium composite microbeads. Biomed Mater 2011, 6:045002. | Article | PubMed

133. Prabhakaran MP, Kai D, Ghasemi-Mobarakeh L, Ramakrishna S: Electrospun biocomposite nanofibrous patch for cardiac tissue engineering. Biomed Mater 2011, 6:055001. | Article | PubMed

134. Kai D, Prabhakaran MP, Jin G, Ramakrishna S: Guided orientation of cardiomyocytes on electrospun aligned nanofibers for cardiac tissue engineering. J Biomed Mater Res B Appl Biomater 2011, 98B:379-386. | Article | PubMed

135. Marsano A, Maidhof R, Wan LQ, Wang Y, Gao J, Tandon N, VunjakNovakovic G: Scaffold stiffness affects the contractile function of three-dimensional engineered cardiac constructs. Biotechnol Prog 2010, 26:1382-1390. | Article | PubMed

136. Schussler O, Coirault C, Louis-Tisserand M, Al-Chare W, Oliviero P, Menard C, Michelot R, Bochet P, Salomon DR, Chachques JC, Carpentier A, Lecarpentier Y: Use of arginine-glycine-aspartic acid adhesion peptides coupled with a new collagen scaffold to engineer a myocardium-like tissue graft. Nat Clin Pract Cardiovasc Med 2009, 6:240-249. | Article 
Teo et al. Journal of Regenerative Medicine \& Tissue Engineering 2012,

http://www.hoajonline.com/journals/pdf/2050-1218-1-4.pdf

I PubMed

137. Fromstein JD, Zandstra PW, Alperin C, Rockwood D, Rabolt JF, Woodhouse KA: Seeding bioreactor-produced embryonic stem cell-derived cardiomyocytes on different porous, degradable, polyurethane scaffolds reveals the effect of scaffold architecture on cell morphology Tissue Eng Part A 2008, 14:369-378. | Article | PubMed

138. Madden LR, Mortisen DJ, Sussman EM, Dupras SK, Fugate JA, Cuy JL, Hauch KD, Laflamme MA, Murry CE, Ratner BD: Proangiogenic scaffolds as functional templates for cardiac tissue engineering. Proc Nat/ Acad Sci U S A 2010, 107:15211-15216. | Article | PubMed Abstract | PubMed Full Text

139. Ifkovits JL, Wu K, Mauck RL, Burdick JA: The influence of fibrous elastomer structure and porosity on matrix organization. PLoS One 2010, 5:e15717. | Article | PubMed Abstract | PubMed Full Text

140. Aubin H, Nichol JW, Hutson CB, Bae H, Sieminski AL, Cropek DM, Akhyari P, Khademhosseini A: Directed 3D cell alignment and elongation in microengineered hydrogels. Biomaterials 2010, 31:6941-6951. | Article | PubMed Abstract | PubMed Full Text

141. Engelmayr GC, Jr., Cheng M, Bettinger CJ, Borenstein JT, Langer R, Freed $\mathrm{LE}$ : Accordion-like honeycombs for tissue engineering of cardiac anisotropy. Nat Mater 2008, 7:1003-1010. | Article | PubMed Abstract | PubMed Full Text

142. Fujita A, Fujita K, Nakamura O, Matsuda T, Kawata S: Control of cardiomyocyte orientation on a microscaffold fabricated by photopolymerization with laser beam interference. J Biomed Opt 2006, 11:021015. | Article | PubMed

143. Yin L, Bien H, Entcheva E: Scaffold topography alters intracellular calcium dynamics in cultured cardiomyocyte networks. Am J Physiol Heart Circ Physiol 2004, 287:H1276-1285. | Article | PubMed

144. Au HT, Cheng I, Chowdhury MF, Radisic M: Interactive effects of surface topography and pulsatile electrical field stimulation on orientation and elongation of fibroblasts and cardiomyocytes. Biomaterials 2007, 28:4277-4293. | Article | PubMed Abstract | PubMed Full Text

145. Shah U, Bien H, Entcheva E: Microtopographical effects of natural scaffolding on cardiomyocyte function and arrhythmogenesis. Acta Biomater 2010, 6:3029-3034. | Article | PubMed

146. Shapira-Schweitzer K, Seliktar D: Matrix stiffness affects spontaneous contraction of cardiomyocytes cultured within a PEGylated fibrinogen biomaterial. Acta Biomater 2007, 3:33-41. | Article | PubMed

147. About the Center for Drug Evaluation and Research $>$ OPS Process Analytical Technology - (PAT) Initiative. I Link

148. Teixeira AP, Duarte TM, Carrondo MJ, Alves PM: Synchronous fluorescence spectroscopy as a novel tool to enable PAT applications in bioprocesses. Biotechnol Bioeng 2011, 108:1852-1861. | Article | PubMed

149. Beutel S, Henkel S: In situ sensor techniques in modern bioprocess monitoring. Appl Microbiol Biotechnol 2011, 91:1493-1505. | Article I PubMed 